\title{
Ustroń-Jaszowiec. Niespełniony sen o socjalistycznym kurorcie (ze studiów nad kulturą wczasów i wypoczynku w PRL-u)
}

\begin{abstract}
Abstrakt: Artykuł traktuje o wczasowym miasteczku Jaszowiec w Ustroniu, stanowiącym wyjątkową w dziejach PRL próbę zrealizowania w praktyce marzenia o wzorcowym, idealnym socjalistycznym kurorcie. Autor identyfikuje i rekonstruuje mechanizmy oraz przesłanki ideologicznego niepowodzenia przedsięwzięcia, zarazem wskazując i tłumacząc przestrzenie ograniczonego (ale realnego) sukcesu Jaszowca jako wypoczynkowej propozycji dla mieszkańców PRL-u. Analizowany w ten sposób kompleks okazuje się „antywzorcem” socjalistycznej budowy.
\end{abstract}

Słowa kluczowe: historia Polski 1944-1989, Ustroń-Jaszowiec, historia i kultura czasu wolnego, Jerzy Ziętek, PRL.

Abstract: The article presents the establishment of the holiday town of Jaszowiec in Ustron, which was a unique attempt in the Polish People's Republic to achieve the dream of a model, ideal socialist resort. The author identifies and reconstructs mechanisms and premises of the ideological failure of the analysed attempt, at the same time indicating and explaining areas of limited (but real) success of Jaszowiec as a leisure design for inhabitants of People's Poland. Thus analysed complex became a kind of 'anti-model' of a socialist construction.

Keyw or ds: History of Poland 1944-1989, Ustroń-Jaszowiec, history and culture of leisure, Jerzy Ziętek, Polish People's Republic. 


\section{Wprowadzenie - problem badawczy}

Gdy turysta lub wczasowicz goszczący w Ustroniu (prosperującej miejscowości wczasowo-sanatoryjnej u stóp masywu Beskidu Śląskiego') obejrzy już sławną na całą Polskę dzielnicę sanatoriów-,,piramid” i zechce opuścić gwarne centrum uzdrowiska, może trafić na miejsce szczególne. Z dala od miejskiej zabudowy, w obszernej i cichej dolinie potoku Jaszowiec na południowym skraju miejscowości, napotka rozległy zespół obiektów turystyczno-wczasowych, po części mocno zaniedbanych, po części odnowionych w ramach lepiej lub gorzej pomyślanych przeróbek ostatnich dekad. Patrząc nieco uważniej, zauważy zapewne ich wciąż utrzymujące się znamienne architektoniczne pokrewieństwo (mimo faktycznie niezwykle zróżnicowanej formy budowlanej) oraz wyraźne ślady funkcjonalnego powiązania. Być może też rozpozna te obiekty jako pochodzące z epoki PRL-u, ale niemal na pewno nie domyśli się, że ogląda jedno z najambitniejszych przedsięwzięć władzy komunistycznej w Polsce w zakresie organizowania obywatelom wypoczynku.

Artykuł zawiera refleksję nad tym właśnie przedsięwzięciem, które stanowiło wyjątkowa, chyba wręcz niepowtarzalna próbę zrealizowania w praktyce marzenia o wzorcowym, idealnym socjalistycznym kurorcie, podjęta w latach rządów Władysława Gomułki². Efekt prowadzonych działań, czyli wzniesienie „od podstaw” całego kombinatu (właściwie wręcz miasteczka) wczasowego w górskiej dolinie opodal administracyjnej granicy Ustronia i Wisły, był pod niektórymi względami naprawdę imponujący i już z tej tylko racji zasługuje na usystematyzowane przedstawienie $\mathrm{w}$ ramach badań nad kultura wypoczywania oraz czasu wolnego tamtej epoki. Ponieważ jednak równocześnie rezultat ten okazał się fundamentalnym niepowodzeniem $\mathrm{w}$ perspektywie wskazanego przed momentem celu zasadniczego, sprawa Jaszowca nadaje się bez wątpienia na szczegółowe case study odnośnie do założeń oraz rozwiązań kształtujących/ wyrażających politykę komunistów w zakresie zarządzania masowym wypoczynkiem ludności w skali kraju. Miast bowiem ziścić sen

${ }^{1}$ Dzieje kurortu w Ustroniu po 1945 r. w najbardziej rozbudowany sposób (acz w pewnym tematycznym rozproszeniu) przedstawili autorzy publikujacy $\mathrm{w}$ drugim tomie monografii Ustronia: Ustroń 1305-2005, t. II: 1945-2005, red. L. Szkaradnik, K. Szkaradnik, Ustroń 2007. Zob. w szczególności: P. Korcz, Lecznictwo ogólne i uzdrowiskowe po 1945 r., w: Ustroń..., t. II, s. 333-383; A. Michałek, Rozwój i charakterystyka budownictwa w Ustroniu, w: Ustroń..., t. II, s. 529-576; L. Szkaradnik, Życie społeczne i polityczne do 1990 r., w: Ustroń..., t. II, s. 117-176. Odnośnie do lat najświeższych zob. H. Guzik, Dziatalność uzdrowiskowa $w$ Ustroniu $w$ latach 2000-2006, „Zeszyty Naukowe Uniwersytetu Ekonomicznego w Krakowie” 2010, nr 821, s. 111-128.

${ }^{2}$ Dostrzegamy tu pewien paradoks, jako że sam Gomułka sprawy wypoczynku i rekreacji miał w zasadzie mocno lekceważyć. P. Sowiński, Wakacje w Polsce Ludowej. Polityka władz $i$ ruch turystyczny (1945-1989), Warszawa 2005, s. 89. Skądinąd fakt małego nimi zainteresowania ze strony przywódcy otwierał relatywnie swobodną przestrzeń kreatywnego działania innym, o ile potrafili „wpisać się” w ustrojowe pryncypia. 
czy marzenie peerelowskich decydentów, kombinat nieoczekiwanie uwydatnił utopijność i dysfunkcjonalność przesłanek, z jakich oni wychodzili oraz strategii, które realizowali. Na tym przede wszystkim koncentrować się będa moje rozważania.

Punktem wyjścia stanie się ogólniejszy namysł nad komunistycznym ideałem wypoczynku dla mas, z którego wyrastały założenia analizowanego przedsięwzięcia. Rozpatrując zasadnicze momenty planowania oraz realizacji jaszowieckiego projektu, wskażę szereg jego szczególnych właściwości, zarówno tych uchwytnych/ uwidaczniających się w trakcie budowy, jak i manifestujących się później w jego architekturze oraz organizacyjnych ramach i formułach działalności. Odnosząc powyższe do ogólnych realiów funkcjonowania gospodarki i społeczeństwa PRL, postaram się następnie rozpoznać zasadnicze pęknięcia i wewnętrzne sprzeczności, jakimi naznaczona została ta - w swoim czasie głośna w skali ogólnokrajowej ${ }^{3}$ - inicjatywa partyjno-państwowych władz regionu Górnego Śląska i Zagłębia Dąbrowskiego (administracyjnie oznaczało to włodarzy „dużego” województwa katowickiego ${ }^{4}$, mniej więcej pokrywajacego się z granicami dzisiejszego województwa śląskiego). Dzięki temu będę $\mathrm{w}$ stanie zidentyfikować i zrekonstruować mechanizmy oraz przesłanki fundamentalnego ideologicznego niepowodzenia analizowanej próby, a jednocześnie wskazać i wytłumaczyć przestrzenie czy obszary ograniczonego (ale jednak realnego) sukcesu Jaszowca jako wypoczynkowej propozycji dla mieszkańców regionu (i nie tylko) w czasach „realnego socjalizmu”.

\section{Wypoczynek w PRL - ideały, cele, organizacja}

Rekonstruując aksjologiczny horyzont powstania jaszowieckich obiektów, przypomnijmy, iż gomułkowską epokę „małej stabilizacji”, podczas której się one zmaterializowały, niewątpliwie znamionowało złagodzenie - do pewnego stopnia - ideologicznej presji, jaką uprzednio (w dobie stalinowskiej) aparat partii komunistycznej wywierał na poszczególne sfery kultury i życia społecznego. Bezdyskusyjne elementy zmiany czy czasem nawet zerwania w zakresie pewnych konkretnych praktyk i form działania nie moga jednak przesłonić faktu, iż aspekt kontynuacji zdecydowanie dominował. PRL lat 1956-1970 to dalszy ciag realizacji tego samego projektu budowy „socjalistycznego społeczeństwa”, który ruszył zaraz po tzw. wyzwoleniu w latach 1944-1945 i następnie rewolucyjnie przyspieszył od schyłku lat

\footnotetext{
${ }^{3}$, „[...] na Jaszowcu wyrósł dosłownie w ciagu minionego dziesięciolecia największy i najnowocześniejszy górski ośrodek wypoczynkowy w Polsce. Kombinat ten stwarza znakomite warunki wypoczynku tysiącom ludzi pracy z całej Polski” - pisano w „Kalendarzu Ślaskim TRZZ na rok 1970”. Cyt. za: P. Korcz, op. cit., s. 349. Podobnych opinii o „oknie wystawowym Beskidów" było zresztą więcej.

${ }^{4}$ To znaczy w granicach sprzed reformy administracyjnej z $1975 \mathrm{r}$.
} 
czterdziestych. Częścią tego projektu było opanowanie, poddanie państwowej kontroli oraz przekształcenie $\mathrm{w}$ duchu ideologii komunistycznej nie tylko sfery publicznej i przestrzeni aktywności zawodowej obywateli, ale też ich życia prywatnego. „Nowy socjalistyczny człowiek” miał zerwać z przeszłościa także w tym obszarze. Czas wolny to pars magna sfery prywatności, w związku z czym dekonstrukcja dotychczasowych form jego spędzania i wprowadzenie nowych, „właściwszych” stanęły w rzędzie zadań uznawanych przez reżim za istotne: praktyki związane $\mathrm{z}$ wypoczywaniem miały odtąd służyć czemuś więcej niż tylko prywatnym potrzebom rekreacji osób w nich partycypujących. Leisure w komunizmie jawił się jako znaczący element systemu $-\mathrm{z}$ funkcją uzupełniania i restytucji w stosunku do innych tworzących go składników ${ }^{5}$.

Obywatele Polski Ludowej powinni zatem wypoczywać grupowo, „[...] co miało stanowić podstawę «wychowania socjalistycznego» i współpracy «opartej na zasadach etyki marksistowskiej»"6. Wypoczynek - w szczególności ten wakacyjny - odbywać się winien poza strukturą (komórka) rodzinną. $\mathrm{Na}$ wczasy - pomijając waską kategorię zasłużonych (jak przodownicy pracy) miano wyjeżdżać samotnie, jako indywidua „zatapiane” następnie we wczasowym kolektywie. W toku pobytu, w ramach tego właśnie kolektywu, dzięki prowadzonej w placówkach wypoczynku tzw. akcji kulturalno-oświatowej (w sporej części stanowiącej formę zawoalowanego szkolenia ideologicznego ${ }^{7}$ ) oraz - niekiedy - także poprzez udział w rozmaitych formach zideologizowanej pracy nieodpłatnej (czyny, pomoc wakacyjna itp.) $)^{8}$, uczestnicy powinni podnosić swoja „świadomość klasową. Masowość opisanych praktyk, tzn. to, że partycypować w nich miały szerokie rzesze, z jednej strony zapewnić winna możliwie największy zasięg takiego „wychowawczego” oddziaływania, a z drugiej zagwarantować właściwy profil społeczny/ klasowy wypoczywajacych; liczebnie przeważające niższe warstwy społeczne (,pracujący lud miast i wsi”)

${ }_{5}^{5}$ Nawiązuję tu do dystynkcji odnośnie do sposobów rozumienia czasu wolnego wymienionych w: K. Migdał, Psychologia czasu wolnego, Warszawa 2011, s. 32.

${ }^{6}$ D. Jarosz, „Masy pracujace przede wszystkim”. Organizacja wypoczynku w Polsce 1945-1956, Warszawa-Kielce 2003, s. 284-285, passim. Autor ten rozpoznaje „ideologizację i polityzacje”, „kolektywizm” oraz „zmianę składu społecznego wypoczywającej populacji” jako zasadnicze właściwości stalinowskiego modelu wypoczynku.

${ }^{7}$ W instrukcji Komisji Centralnej Związków Zawodowych z 1949 r. (to właśnie związkom powierzono prowadzenie wczasów za pośrednictwem instytucji Funduszu Wczasów Pracowniczych) czytamy m.in.: „[...] zwrócić specjalną uwagę na zorganizowanie: 1) prasówki z aktualnymi informacjami politycznymi, 2) pogadanki o: a) Polsce współczesnej, b) zagadnieniach gospodarczych, c) ruchu robotniczym [...], 3) ewentualnie wieczoru dyskusyjnego (zależnie od tego czy w danym domu znajduje się odpowiedzialny towarzysz partyjny [...]. Dla urządzenia pogadanek i dyskusji należy wykorzystywać przyjeżdżający aktyw związkowy i partyjny”. Cyt. za: ibidem, s. 76. Przywoływane przez tego autora dane źródłowe zaświadczaja, że faktycznie starano się takie zalecenia realizować.

${ }^{8}$ P. Sowiński, op. cit., s. 66-67. 
musiały w takim wypadku dominować. Jak zauważał Paweł Sowiński, ruch wypoczynkowy miał w pierwszym rzędzie posiadać oblicze właśnie robotnicze i chłopskie, a kurorty winny pozbyć się dotychczasowego „burżuazyjnego stylu życia”, ujemnie wpływającego na wczasowiczów ${ }^{9}$. Łatwo tu zauważyć elementy społecznej inżynierii. Doświadczenie wypoczynku w uzdrowiskowej/ wczasowej miejscowości - w określony sposób „sformatowane” przez rządzących - miało się odtąd stać możliwie powszechne ${ }^{10}$. Nie tylko powinno ustanawiać jeszcze jedna nić zależności obywatela od kontrolujaccej go władzy (władzy „dobrej”, „opiekującej się"), ale miało pomóc w likwidacji istotnego residuum dawnych wzorców kulturowych oraz społecznych stratyfikacji, jakim pozostawała zastana kultura wczasowa i uzdrowiskowa ${ }^{11}$.

W dobie „gomułkowskiej” zasadnicze cele władzy „na odcinku” wczasów nie zmieniły się, zarazem jednak formułowane były w kontekście efektów i doświadczeń dotychczasowej polityki. Do 1956 r. komunistom niewątpliwie powiodło się zakorzenienie idei urlopu i wczasów w społeczeństwie ${ }^{12}$. Niektórzy studiujący te zagadnienia autorzy utrzymują nawet, że „zepchnięto do zbiorowej nieświadomości inne niż oficjalnie propagowane sposoby spędzania wolnego czasu"13. Zarazem swoją dysfunkcjonalność uwydatniła część wprowadzonych rozwiązań, w tym w szczególności zasada wczasów bez rodziny, skrajna centralizacja zarządzania wypoczynkiem przez Fundusz Wczasów Pracowniczych (FWP), jawne zideologizowanie działalności kulturalno-oświatowej na wczasach. Aby skutecznie - w warunkach nieco teraz powiększonej (także w sferze czasu wolnego) autonomii społeczeństwa - podnosić poziom jego identyfikacji z państwowym modelem rekreacji, trzeba było wprowadzić korekty. FWP zaczął w stale powiększającej się skali oferować wczasy dla

${ }^{9}$ Ibidem, s. 35; D. Jarosz, op. cit., s. 22.

${ }_{10}$ Niewatpliwie do owego momentu było ono obce i - jak to celnie opisał wspomniany Jarosz wcale nie łatwe do kulturowego przyswojenia dla zdecydowanej większości intensywnie wciaganych przez władzę w obręb wypoczynkowej machiny przedstawicieli warstwy robotniczej oraz chłopskiej. Zob. D. Jarosz, op. cit., s. 81-84. Por. P. Sowiński, op. cit., s. 46.

${ }^{11}$ Istotnego z tej na przykład racji, że wciąż stanowiącego punkt odniesienia dla wielu oczekiwań/ zachowań manifestowanych przez wyjeżdzających na wczasy - także tych o „proletariackim” rodowodzie. Ogólnie o ewolucji modelu wypoczywania mieszkańców Polski w XX stuleciu zob. B. Płonka-Syroka, Kultura uzdrowiskowa $w$ Polsce $w$ latach 1918-2012. Społeczno-kulturowe uwarunkowania zmiany jej modelu, w: Zdrowie i choroba. Wptyw jakości życia na kulturę w Europie Środkowej, red. A. Barciak, Katowice 2013, s. 174-200. Zob. też: Z. Skórzyński, Wzory społeczne wakacji w Polsce - ważniejsze wyniki badań, w: Wzory społeczne wakacji $w$ Polsce. Studia i materiaty z badań socjologicznych, red. Z. Skórzyński, A. Ziemilski, t. II, Warszawa 1971, s. 305-312.

${ }^{12}$ Co skądinąd rzeczywiście modernizowało pewne sfery i praktyki życia zbiorowego.

${ }_{13}$ P. Sowiński, op. cit., s. 90. To na pewno przesada, ponieważ wciąż na wczasy wyjeżdżała (prawda, że dynamicznie rosnacca) mniejszość. Właściwiej byłoby rzec, iż zdołały się one upowszechnić w społecznej świadomości jako dobro wysoce pożądane. Zob. Z. Skórzyński, Typologia $i$ zasięg społeczny wzorów wakacyjnych $w$ Polsce $w$ świetle badań reprezentatywnych, w: Wzory społeczne..., t. I, s. 209-218. 
całych rodzin, a od końca lat pięćdziesiątych uruchamiano alternatywna dla Funduszu formułę tzw. rodzinnych wczasów zakładowych, które rychło „przebiły” jego ofertę w wymiarze ilościowym, a nierzadko też jakościowym. W tym wypadku inwestorami powstajacej bazy wypoczynkowej zostawały zakłady pracy; one też (samodzielnie albo poprzez związki zawodowe danej branży) nią zarządzały. Modyfikacje objęły również pracę wychowawczą na turnusach.

Wycofano się z najbardziej radykalnych akcji propagandowych - odnotowywał Sowiński - Jednak nie zrezygnowano z nich zupełnie. Za symbol zmian w tej sferze można uznać wprowadzenie do obiegu pojęcia instruktora kulturalno-rozrywkowego, znanego w czasach stalinowskich raczej pod nazwą kulturalno-oświatowego, który niegdyś miał dbać o kształtowanie światopoglądu wypoczywających, a po roku 1956 częściej stawał się tylko organizatorem życia wczasowego ${ }^{14}$.

Jednak stalinowska idea wczasów jako „remontowni ciał i dusz” ${ }^{15}$ wciąż pozostawała obecna - co prawda teraz przybierana w mniej zideologizowane, a bardziej naukowe czy humanistyczne formuły ${ }^{16}$.

[...] Wczasy w pełnym, nowoczesnym tego słowa znaczeniu - pisano na przykład - to nie tylko troska o regenerację sił biologicznych ludzi pracy, ale i dbałość o wzrost ich społecznej świadomości i wytrwałe dążenie do rozbudzenia drzemiących w masach potrzeb poznawczych i estetycznych. Tylko w ten sposób pojmowane wczasy stać się moga źródłem zdrowia duchowego i fizycznego. [...] W ustroju socjalistycznym obie strony życia - praca i wypoczynek - dotychczas rozmyślnie i skutecznie rozdzielane stanowią jedną, harmonijną całośćc ${ }^{17}$.

${ }^{14}$ P. Sowiński, op. cit., s. 93. Szerzej o przejściu do epoki gomułkowskiej „na odcinku” wypoczynku zob. ibidem, s. 89 i n. O dalszym jednak trwaniu - zawoalowanej i zręczniej niż dawniej prowadzonej - indoktrynacji w trakcie wypoczywania zob. ibidem, s. 209-210 i n.

${ }^{15}$ Określenie przypisywane Stanisławowi Ossowskiemu przytaczam za Sowińskim. Ibidem, s. 87.

${ }^{16}$ Sprawozdawczo odnośnie do ewolucji tych formuł zob. B. Łobodzińska, Ewolucja założeń programowych wczasów pracowniczych w Polsce Ludowej w latach 1945-1965, w: Wzory spoteczne..., t. I, s. 143-184. Zob. też: T. Aleksander, Kultura wypoczynku na wczasach, Warszawa 1986, s. 8-9, passim.

${ }_{17}$ J. Dobrzyński, Wczasy i zdrowie, Warszawa 1967, s. 7-8, cyt. za: R. Okrasa, Wczasy pracownicze. System organizacyjny, Warszawa 1979, s. 6-7. Inny z kolei autor podkreślał: „Zgodnie z osiaganą w socjalizmie jednością [podkreślenie oryginalne - T.P.] podzielonego czasu człowieka - mowa o jego czasie pracy i wypoczynku - i w związku z tym określona rolą urlopów oraz wczasów w naszej polityce społeczno-kulturalnej, szczególnie zależy nam na tym, by ludzie pracy przeżywali swój wielki czas wolny [takim terminem opatrywano okres urlopu - T.P.] coraz bardziej świadomie i celowo. By ich urlop nie był tylko okresem błogiej bezczynności czy absolutnej dowolności, ale stanowił ważny etap w procesie ich wewnętrznego rozwoju, ich mniej czy bardziej ambitnej samorealizacji. W tym celu mówiąc skrótowo - urlop winien być zwierciadłem i akumulatorem roku, pomyślanym jako jedyna, doroczna szansa konfrontacji siebie i swej kondycji z innymi ludźmi i zadaniami, jakie nas czekaja”. A. Gładysz, Wczasy w Jaszowcu, Katowice 1974, s. 14. 


\section{Wypoczynkowe miasto - nadzieje i rzeczywistość}

Jaszowiec intencjonalnie wzniesiono pod takie właśnie oczekiwania. Wypoczywać i relaksować się w nim mieli - w wyżej opisany „twórczy” i „konstruktywny" sposób, korzystając z rozległej, zróżnicowanej infrastruktury czasu wolnego $^{18}$ - pracownicy śląsko-zagłębiowskich przede wszystkim (acz niewyłącznie) zakładów pracy, z reguły zaliczających się do wielkich, strategicznie ważnych gospodarczo, przedsiębiorstw państwowych doby PRL. Przyjęto, że urlopowe miasteczko funkcjonować będzie w oparciu o wzmiankowaną wyżej formułę zakładowych wczasów rodzinnych. Przesądził to zreszta z góry sposób sfinansowania inwestycji - środków na budowę dostarczyły konkretne państwowe przedsiębiorstwa i branżowe zjednoczenia zainteresowane pozyskaniem bazy wypoczynkowej dla swoich pracowników. Podmioty te stały się następnie właścicielami poszczególnych wzniesionych w ramach kompleksu obiektów i samodzielnie nimi zarządzały. W ten sposób - jak wierzono skutecznie będzie można spełniać postulat ideologicznie pierwszoplanowy w odniesieniu do wczasów, a do tej pory mimo wszelkich starań realizowany wybitnie niezadowalajacc ${ }^{19}$, aby wiodacym beneficjentem oferowanego przez państwo wypoczynku rzeczywiście stały się masy pracujące, w szczególności zaś wielkoprzemysłowa klasa robotnicza.

Ustroń-Jaszowiec zatem naprawdę stanowić miał wzorcową realizację w zakresie rozwijania masowego, organizowanego przez państwo wypoczynku oraz rekreacji w warunkach społeczeństwa i gospodarki „realnego socjalizmu”. Prezentował się jako „kurort idealny” w perspektywie lansowanych przez władze komunistyczne społeczno-kulturowych wzorców odnośnie do tego, jak powinien wypoczywać, relaksować się i dbać o zdrowie standardowy obywatel PRL wraz z rodzina - przedstawiciel „klasy robotniczej” i/lub „inteligencji pracującej”. Obrazował też funkcjonowanie - intencjonalnie od „najlepszej” strony - nowo przyjętych/ wdrażanych wtedy przez rządzących całościowych rozwiązań organizacyjnych w zakresie masowego wypoczynku i rekreacji (taki bowiem charakter miały - nieznane czasom stalinowskim - wczasy zakładowe). Ustanawiał on także pewien wzorzec $\mathrm{w}$ zakresie procesu realizowania złożonego, całościowego przedsięwzięcia inwestycyjnego w sferze budowy/

${ }_{18}$ Zwróćmy uwagę, że przytoczony w poprzednim przypisie cytat pochodzi z socjologicznego studium, którego naukowym, a zarazem praktyczno-użytkowym celem było zdiagnozowanie, czy rzeczywiście Jaszowiec oczekiwania takie zdołał spełnić. Do wyników tej diagnozy, a także szczególnych losów przedstawiającej ją publikacji, wrócę w dalszej części studium.

19 Dokumentowały to obszernie zarówno sprawozdania FWP i Centralnej Rady Związków Zawodowych, jak i na bieżąco prowadzone studia peerelowskich badaczy społecznych. Syntetycznie na temat tych ustaleń zob. D. Jarosz, op. cit., s. 43-63; P. Sowiński, op. cit., s. 110-111. Zob. też: J. Sierpiński, Wczasy pracownicze w Polsce Ludowej. Problematyka ekonomiczna i społeczna, Warszawa 1968, s. 71-76; R. Walicki, Polityka społeczna zakładów pracy $w$ sferze wypoczynku urlopowego, Warszawa 1985, s. 47-55. 
rozbudowy kompleksowej bazy wypoczynkowo-sanatoryjnej. Mówiąc ściślej, Jaszowiec prezentowano jako swoisty „poligon” w kwestii wypracowywania i praktycznego testowania rozwiązań organizacyjnych oraz menedżerskich, intencjonalnie przyspieszajacych/ optymalizujących realizację inwestycji tego rodzaju w warunkach gospodarki planowej ${ }^{20}$.

Umiejscowienie kompleksu w administracyjnych granicach Ustronia miało ponadto zmienić charakter samej miejscowości. Do tej pory, w aspekcie wypoczynkowo-sanatoryjno-uzdrowiskowym, jednoznacznie dominowała w miasteczku „niepoprawna politycznie” tradycja sprzed wojny, wyrażająca się gęstą siecią eleganckich pensjonatów i „willi na wynajem” dostosowanych do potrzeb przyjeżdżającej indywidualnie „do wód i na wywczasy” zamożniejszej klienteli z wielkich miast (burżuazyjny, „urzędniczo-pensjonatowy” wzorzec wakacyjnego i sanatoryjnego wypoczynku) ${ }^{21}$.

Formalny początek przedsięwzięcia stanowiła seria decyzji władz państwowych szczebla wojewódzkiego (tzn. uchwał Prezydium Wojewódzkiej Rady Narodowej w Katowicach) z lat 1959-196022, nakazujących budowę zintegro-

${ }^{20}$ Zamierzano bowiem w przyszłości zbudować więcej „miasteczek wczasowych z pełną infrastruktura potrzebną do racjonalnego wypoczynku". R. Okrasa, Wczasy..., s. 89. W prasie regionalnej z kolei wprost pisano o majacych powstawać w Beskidzie Ślaskim „bliźniakach” Jaszowca. Zob. np.: Bliźniak Jaszowca stanie w Wiśle, „Głos Ziemi Cieszyńskiej”, 4 VIII 1963, nr 31, s. 1-2. Por. G. Sztwiertnia, Kombinat uzdrowiskowo-wypoczynkowy, w: Cieszyn. Zarys rozwoju miasta i powiatu, red. J. Chlebowczyk, Katowice 1973, s. 622-626.

${ }^{21} \mathrm{Na}$ temat działalności uzdrowiskowej w Ustroniu przed 1939 r. zob. L. Szkaradnik, Poczatki i rozwój uzdrowiska, w: Ustroń..., t. I: 1305-1945, red. I. Panic, Ustroń 2005, s. 361-380. Zob. też: L. Szkaradnik, Poczatki uzdrowiska w Ustroniu, „Kalendarz Ustroński” 2001 s. 37-43; R. Kincel, Rozmaitości z poczatków kurortu, „Kalendarz Ustroński” 2003, s. 37-52; idem, Lata dwudzieste, lata trzydzieste, „Kalendarz Ustroński” 2004, s. 41-47; Z. Białas, Ustrońskie tazienki borowinowe, „Kalendarz Ustroński” 2003, s. 72-77; idem, Ustroński kurort w połowie XIX wieku, „Kalendarz Ustroński” 2010, s. 236-253; idem, Ustroński kurort w latach 1858-1876, „Kalendarz Ustroński” 2011, s. 70-83; J. Pilch, Rozwój Ustronia jako letniska i uzdrowiska (do r. 1939), „Pamiętnik Ustroński” 1989, t. II, s. 3-14; A. Michałek, Rozwój i charakterystyka budownictwa..., s. 542-545; B. Kubień, Historia budownictwa $w$ Ustroniu, „Pamiętnik Ustroński” 2001, t. XI, s. 20-39. Warto zaznaczyć, że przez dziesięciolecia z funkcją kurortu rywalizowała w Ustroniu funkcja przemysłowa (przede wszystkim hutnictwo i metalurgia), a liczba mieszkańców zatrudnionych w przemyśle wielokrotnie przewyższała tych zatrudnionych w sferze turystyki, wypoczynku oraz lecznictwa uzdrowiskowego. Dopiero w PRL odgórnie rozstrzygnięto ustroński dylemat rozwojowy na rzecz tej ostatniej sfery. Stworzenie kurortu właśnie dla robotników było zatem swoistym nawiązaniem do tej drugiej, aktualnie wypieranej, tożsamości Ustronia... Więcej o tej szczególnej koincydencji, w tym zwłaszcza o takich aspektach działalności miejscowego przemysłu, które wydatnie wspomagały (sic!) realizowanie praktyk leczniczo-uzdrowiskowych (zastosowanie gorących odpadów/ żużli hutniczych przy leczniczych kapielach), zob. E. Gonda-Soroczyńska, Nietypowe połaczenie funkcji uzdrowiskowej $z$ funkcja przemystowa na przyktadzie uzdrowiska Ustroń, „Infrastruktura i Ekologia Terenów Wiejskich” 2013, nr 3, s. 31-45.

${ }^{22}$ Kluczowe były uchwały z 24 II 1959 i 11 III 1960 r. Archiwum Państwowe w Katowicach (dalej: APK), Prezydium WRN w Katowicach (dalej: PWRNK), Protokoły posiedzeń Prezydium 
wanego zespołu turystyczno-wypoczynkowego w nieomal wtedy pustej dolinie Jaszowca ${ }^{23}$, powołujacych specjalną strukturę administracyjną dla realizowania tego przedsięwzięcia (Wojewódzka Komisja Koordynacyjna ds. budowy ośrodka regionalnego w Ustroniu) i zlecajacych katowickiemu oddziałowi Stowarzyszenia Architektów Polskich przeprowadzenie ogólnopolskiego konkursu architektonicznego na całościowy projekt inwestycji. Do realizacji przyjęto zwycięską w tym konkursie propozycję czworga katowickich architektów ${ }^{24}$, odrobinę zmodyfikowana po rozpoczęciu szczegółowych prac projektowych. Zaplanowano trzy odrębne architektonicznie grupy budynków wczasowych, na różne sposoby (ale zawsze bardzo oryginalnie i efektownie) dopasowujace się do pochyłego, górskiego terenu południowo-zachodnich stoków Równicy, gdzie je wszystkie - na zróżnicowanych wysokościach licząc od dna doliny posadowiono. Pierwszą grupę stanowiły cztery budowle nazwane „gronowcami”. W każdym z nich asymetrycznemu, podłużnemu, piętrowemu budynkowi głównemu, mieszczącemu (na górnym poziomie) wejście z recepcja, a ponadto kawiarnię, jadalnię, kuchnię i wszelkie inne pomieszczenia wspólne (w tym salę TV), towarzyszył zespół pięciu rozmieszczonych niżej na stoku piętrowych pawilonów hotelowych; od budynku głównego zbiegał do nich po pochyłym terenie przeszklony, rozgałęziony korytarz - w rzeczy samej całość z lotu ptaka trochę przypominała rzuconą w poprzek zbocza owocujaca gałązę

WRN z lat 1950-1973, 12/224/0/1.16/1693 (prot. nr 5 z 24.02.59) i 12/224/0/1.16/1730 (prot. nr 8 z 11.03.60); ibidem, Realizacje uchwał z lat 1951-1973, Sprawozdanie z wykonania uchwał Prez. WRN za rok 1959 i 1960, 12/224/0/1.17/2264 i 12/224/0/1.17/2265. Zob. też: APK Oddział Cieszyn (dalej: APK OC), Prezydium MRN w Ustroniu (dalej: PMRNU), 18, Protokoły sesji MRN (prot. z 21.01.61). Oczywiście powyższe poprzedziło - najważniejsze w ówczesnych realiach ustrojowych - postanowienie Komitetu Wojewódzkiego PZPR (z 19 I 1959). Wydarzenie te relacjonowała prasa: Uzdrowisko Wista-Ustroń bliskie realizacji, „Głos Ziemi Cieszyńskiej”, 10 III 1960, nr 9, s. 1; J. Ziętek, Budowa największej w kraju inwestycji wczasowej $w$ Wiśle-Ustroniu, „Głos Ziemi Cieszyńskiej”, 14-20 IV 1961, nr 15, s. 4; Budowa olbrzymiego kombinatu leczniczo-wypoczynkowego Wista-Ustroń rozpoczęta, „Głos Ziemi Cieszyńskiej”, 11-17 VIII 1961, nr 32, s. 3, 6. Zob. też: H. Lipowczan, Jaszowiec, Katowice 1970, s. 14-17. Plany były zreszta szersze, dotyczyły zagospodarowania wypoczynkowo-sanatoryjnego całego Beskidu Śląskiego na osi Ustroń-Wisła/ Szczyrk-Istebna. Projekt Jaszowca stanowił tylko etap początkowy tych śmiałych zamierzeń.

${ }^{23} \mathrm{~W}$ rozległej dolinie o równoleżnikowo przebiegającej osi, z potwierdzonym korzystnym mikroklimatem i wysokim poziomem nasłonecznienia, znajdowało się nieco rozproszonych prywatnych zabudowań małego przysiółka oraz dwa domy wypoczynkowe: duży przedwojenny obiekt katowickiego koncernu Huta Pokój o efektownych modernistycznych kształtach „stylu okrętowego" i niewielki dom Poczty Polskiej. Dnem doliny przebiegała turystyczna droga na szczyt Równicy.

${ }^{24}$ Irena Kotela, Czesław Kotela (w owym czasie architekt wojewódzki w Katowicach), Jerzy Winnicki, Zygmunt Winnicki. W APK OC (PMRNU, 74) zachował się pierwotny, szczegółowy plan „Dzielnicy Wczasowej Jaszowiec” z 1960 r. Za projekt i jego realizację zespół uhonorowano w 1968 Nagrodą Ministra Budownictwa. „Głos Ziemi Cieszyńskiej”, 8 IX 1968, nr 36, s. 1. 
winorośli. Druga grupę tworzyły cztery domy zwane „liniowcami”. Na każdy składały się dwa proste, bardzo wydłużone (,pasmowe”) dwukondygnacyjne budynki sytuowane w poprzek stoku, jeden nad drugim, ze „spływającym” po pochyłości szklanym korytarzem-łącznikiem. Wejście i gros pomieszczeń wspólnych znajdowały się na wyższym piętrze górnego obiektu, reszta (m.in. kawiarnia) - w centralnych częściach pozostałych kondygnacji. Pokoje dla gości natomiast zajmowały rozległe skrzydła ${ }^{25}$. Ostatnią grupę - lokowana najwyżej i najdalej w głębi doliny - określono mianem „punktowców” lub „wielotraktowców”. Było to sześć pięciokondygnacyjnych zwartych konstrukcji, których wyraziste, wyrastajace ze zbocza i „chwytające słońce” fasady „cofały się" z piętra na piętro, imitując w ten sposób pochył górskiego stoku, na którym budowle wzniesiono (zostawiając przestrzeń na wielkie balkony oraz tarasy). Wspólne pomieszczenia użytkowe umieszczono na zapewniających najlepsze widoki górnych kondygnacjach, niżej pokoje (od frontu) i pomieszczenia gospodarcze (z tyłu od strony zbocza, tam było wejście, w połowie wysokości budowli). Do tego dochodził jeszcze umiejscowiony blisko dna doliny jeden dwukondygnacyjny obiekt jednoliniowy - podwójnie „łamany”, z pomieszczeniami wspólnymi zajmującymi jedno ze skrzydeł. Pokoje w domach wczasowych otwarto na słońce, wszystkie miały balkony i umywalkę z bieżąca woda, aczkolwiek łazienki oraz sanitariaty pozostawały wspólne („,na korytarzu”). Łaczna liczba miejsc noclegowych wynosiła 2,5 tys. ${ }^{26}$

W połowie wysokości zbocza, pomiędzy „gronowcami” a „liniowcami”, ulokowany został kompleks handlowo-usługowy - efektownie spiętrzony zespół siedmiu pawilonów mieszczących widokową kawiarnię, klub z sala widowiskowa, sklepy, pocztę i punkty usługowe; całość łączyły tarasy i zespoły spływających po zboczu schodów. Na dnie doliny wzniesiono ponadto budynek ośrodka zdrowia. Wszędzie doprowadzono gaz ziemny - to niestandardowe jeszcze wtedy rozwiązanie wyeliminowało uciążliwe środowiskowo użytkowanie węgla w kuchniach i przy ogrzewaniu budynków. Ciag drogowo-komunikacyjny pozwalał na pełne okrążenie doliny: wiódł najpierw jej dnem w głąb, powracając następnie ku wylotowi zboczem powyżej większości domów wczasowych (każdy miał wydzieloną drogę dojazdową z parkingiem, odchodząca od głównego traktu). W ten sposób nie tylko zapewniono dobry dojazd do

${ }^{25}$ Do tej grupy dopasowano znajdujący się w pobliżu dotychczasowy obiekt pocztowców poprzez dobudowanie poniżej istniejącego budynku nowej, zasłaniającej go konstrukcji o charakterze „linii”, architektonicznie identycznej z budowlami wyżej opisanymi - dzięki temu w widoku z dołu doliny całość prezentowała się jako piąty „liniowiec”.

${ }^{26}$ Dla porównania: 20 lat później łączna liczba miejsc noclegowych we wszystkich domach wczasowych nieodległego Szczyrku, miasta uchodzącego za jedno z większych centrów sportu i wypoczynku w Polsce, dochodziła zaledwie do 2,8 tys. (plus trudna do oszacowania - ale chyba porównywalna - liczba miejsc w kwaterach prywatnych). W. Błasiak, M.S. Szczepański, J. Wódz, Szczyrk - miasto w sytuacji inwazji turystycznej (socjologiczne studium uktadu lokalnego), Katowice 1990, s. 65 i n. 
wszystkich obiektów, ale też wykreowano na stokach obszerna przestrzeń izolowaną od ruchu kołowego. Przecinały ją na różnych wysokościach utwardzone i oświetlone aleje spacerowe, przy domach wczasowych były przestrzenie do zimowych zjazdów sankami. Na dole zarezerwowano miejsce na 15 (sic!) boisk do gier zespołowych (siatkówka, koszykówka, piłka nożna), 4 korty tenisowe, zespół basenów kapielowych, place zabaw dla dzieci oraz otwarte zimowe lodowisko. Miała też powstać muszla koncertowa. Założono samowystarczalność kompleksu jako wyodrębnionego przestrzennie, samodzielnego wypoczynkowo-uzdrowiskowego miasteczka, stanowiącego zbiór różnorodnych funkcjonalnie obiektów użytkowych zintegrowanych z terenem i odpowiednio zaaranżowanym krajobrazem. Infrastruktura w dolinie winna zaspokajać całość potrzeb bytowych i rekreacyjnych przybywających gości, a w części domów miałyby być dla nich dostępne zabiegi sanatoryjne. Ponadto przy wylocie doliny Jaszowca zlokalizowany był - na linii kolejowej Wisła-UstrońGoleszów - przystanek pasażerski Ustroń Polana, co umożliwiało dogodne dojazdy pociagiem z przemysłowych miast konurbacji śląsko-dąbrowskiej.

Budowa - najpierw elementów infrastruktury wspólnej (mosty, drogi, linie energetyczne, gazociag, wodociąg, oczyszczalnia ścieków z kolektorami etc.), a potem kolejnych domów wczasowych - ruszyła w 1961 r. Dwa lata później przekazano do użytkowania pierwszy obiekt („łamany jednoliniowiec” „Dom Nauczyciela”), następnie sukcesywnie kolejne domy, ośrodek zdrowia i centrum handlowo-usługowe. Wytyczano alejki. W toku prac pokonano wiele nieoczekiwanych trudności technicznych, jakie rodził ten, niewątpliwie niestandardowy, górski plac budowy. W 1970 r. inwestycję zamknięto. Nie powstały baseny, boiska i muszla koncertowa; w dolinie funkcjonował (jednak dopiero dużo później) jeden kort tenisowy ${ }^{27}$. Z czasem na przeciwnym stoku

\footnotetext{
${ }^{27}$ Najbardziej kompletny i bogaty w liczne (choć podawane w retoryce „propagandy sukcesu”) szczegóły drukowany opis powstawania Jaszowca zob. H. Lipowczan, op. cit. Zob. też: M. Pilch, Jaszowiec, „Pamiętnik Ustroński” 2001, t. XI, s. 73-78; G. Sztwiertnia, op. cit., zwłaszcza s. 621-625. Obszernie i na bieżąco postępy inwestycji opisywała prasa lokalna. Zob. m.in.: Pierwszy dom wypoczynkowy $w$ dolinie Jaszowca będzie gotowy $w$ tym miesiącu, „Głos Ziemi Cieszyńskiej”, 16 VI 1963, nr 14, s. 1; Ośrodek leczniczo-wypoczynkowy dla nauczycieli - otwarty!, „Głos Ziemi Cieszyńskiej”, 4 VIII 1963, nr 31, s. 1; Wkrótce $w$ Jaszowcu nowe obiekty wczasowe, „Głos Ziemi Cieszyńskiej”, 5 VI 1966, nr 23, s. 1; Kształtuje się nowe oblicze Ustronia, „Głos Ziemi Cieszyńskiej”, 26 VI 1966, nr 26, s. 1-2; Wielkie perspektywy matego Ustronia, „Trybuna Robotnicza”, 3 IV 1968, nr 80, s. 1, 3. Dokładne informacje o postępie prac, pojawiajacych się trudnościach organizacyjno-technicznych oraz „na bieżąco” wypracowywanych sposobach ich pokonywania, zawieraja protokoły obrad Prezydium Miejskiej Rady Narodowej w Ustroniu i ich dokumentacyjne załączniki. Zob. w szczególności: APK OC, PMRNU 1965, 52 (prot. 14 z 22.11.65); APK OC, PMRNU 1966, 53 (prot. 31 z 1.08.66 i prot. 39 z 7.11.66); APK OC, PRMNU 1967, 54 (prot. 55 z 19.06.67); APK OC, PMRNU 1968, 55 (prot. 82 z 3.06.68); APK OC, PMRNU 1969, 56 (prot. 100 z 3.02.69); APK OC, PMRNU 1970, 57 (prot. 20 z 3.03.70); APK OC, PRMNU 1968, 25, Protokoły sesji MRN (prot. 37 z 10.06.68).
} 
doliny zainstalowano jeszcze wyciag narciarski ${ }^{28}$. W opisanym kształcie, jako względnie ujednolicona całość funkcjonująca w ramach obowiązujących wtedy państwowych mechanizmów organizowania masowego wypoczynku, kompleks Jaszowca przetrwał do końca PRL.

\section{Niepowodzenia projektu Jaszowca}

Efektowny architektonicznie oraz inżyniersko zespół Jaszowca wielokrotnie - w czasie budowy oraz później - przedstawiano jako wielki sukces socjalistycznego budownictwa i organizacji pracy, spektakularny „przykład dobrej roboty" (by przywołać nowomowę z kolejnej, gierkowskiej epoki PRL, w której początkach kompleks zdołał dopiero w pełni rozwinąć swoją działalnośćc ${ }^{29}$ oraz oczywiste świadectwo realnej i skutecznej troski ludowego państwa o dobrostan obywateli - w szczególności tych wypoczywających na wczasach. Zdawał się on zatem „wizytówką" Polski Ludowej tamtych lat, jakże przydatną propagandowo ówczesnym rządzącym ${ }^{30}$. Na czym więc polegało, w jaki sposób się wyrażało, a wreszcie z czego wynikało niepowodzenie projektu Ustronia-Jaszowca?

Porażka miała kilka aspektów, a jej element najbardziej zapewne dotkliwy bo dotykający sedna ideologii stojącej za całym przedsięwzięciem - ujawnił się całkiem rychło, przy tym w okolicznościach dodatkowo kłopotliwych z perspektywy rządzacych. Stało się tak za sprawą badań socjologicznych nad praktykami wypoczywania w jaszowieckim kompleksie. „Studia procesu wczasowego" w dolinie prowadzono we wczesnych latach siedemdziesiatych pod auspicjami Ślaskiego Instytutu Naukowego w Katowicach, oficjalnie regionalnej instytucji naukowo-badawczej na Górnym Ślasku (w tym wymiarze deklarującej się jako swego rodzaju kontynuacja przed- i tużpowojennego Instytutu Śląskiego), w dużym stopniu jednak funkcjonującej - w tamtych zwłaszcza latach - jako usługowy ośrodek ekspercko-propagandowy miejscowych instancji PZPR ${ }^{31}$. I oto sygnowany przez taką właśnie instytucję raport (przygotowany przez socjologa Antoniego Gładysza) wykazywał, że „[...] ośrodek pracowniczych wczasów rodzinnych w Jaszowcu [...] nie spełnia aktualnie roli nowoczesnego, wyjątkowo udanego czy chociażby wzorowego

${ }^{28}$ Dodać wypada, iż od 1967 r. vis-à-vis wylotu doliny Jaszowca funkcjonowała całoroczna kolejka krzesełkowa na Czantorię; zimą uruchamiano tam kilka tras narciarskich. L. Szkaradnik, Od gminnej do miejskiej Rady Narodowej, w: Ustroń..., t. II, s. 35.

${ }^{29}$ H. Lipowczan, op. cit., s. 27-28; A. Jurkiewicz, Uroki Ustronia, „Trybuna Robotnicza”, 15-16 II 1969, nr 39, s. 1, 3.

30 Towarzyszący kurortowi rozgłos prasowy, który tylko po części tu udokumentowano, przekonująco o tym zaświadcza.

31 Więcej na jej temat zob. M. Fic, Między nauka a propagandq. Ślaski Instytut Naukowy im. Jacka Koraszewskiego w Katowicach (1957-1992), Katowice 2014. 
jak o tym co jakiś czas próbuje informować prasa, ko mbinatu [podkreślenie oryginalne - T.P.] wypoczynku i rekreacji” ${ }^{32}$. W świetle badań kompleks funkcjonował zadowalająco (czy nawet - według zwrotnych opinii ankietowanych uczestników turnusów - bardzo dobrze), przede wszystkim w zakresie zapewnienia warunków do „biernego wczasowania” w klimacie górskim: wygodne lokum, dobre posiłki, miejsca do wylegiwania się na słońcu oraz (najmniej pożądanych z punktu widzenia organizatorów wypoczynku, ale praktykowanych powszechnie) „siedzacych” rozrywek „karciano-alkoholowych”. Dalece niedostateczne były natomiast możliwości wypoczynku czynnego, innego niż samodzielna, indywidualna eksploracja okolicznych pasm górskich. Jego potrzeba u wypoczywających, „wymagająca odpowiednich urządzeń i fachowych umiejętności personelu usługowego", pozostawała zatem niezaspokojona ${ }^{33}$. Jeszcze gorzej miał się przedstawiać „stan kultury rozrywkowej”:

[...] organizatorzy życia kulturalno-rozrywkowego nie tylko nie byli w stanie wzbogacić świadomości swych podopiecznych [...] ale nawet nie sprostali zadaniu zaspokojenia odczuwanych przez wczasowiczów najpilniejszych potrzeb rozrywki czynnej. Wnioski z konfrontacji oczekiwań samorealizacyjnych z rzeczywistościa - kontynuował dalej socjolog - są również mało pocieszające ${ }^{34}$.

$\mathrm{Na}$ długiej liście zarzutów uwagę zwracało też podniesienie, jako poważnego zagadnienia, strukturalnego konfliktu wczasowiczów dorosłych oraz wypoczywających rodzin z dziećmi (dla małoletnich nie było ani wydzielonych przestrzeni, ani żadnej specjalnej oferty) ${ }^{35}$. Mówiąc krótko: lansowana przez komunistyczną władzę wizja wypoczynku wysokiej jakości, pozwalającego nie tylko banalnie „odetchnaćc" po trudzie całorocznej pracy, ale i zaspokajającego bardziej dojrzałe czy wysublimowane - ujęte w duchu peerelowskiej aksjologii oczywiście - potrzeby odwiedzających kurort (a najlepiej - kreującego je u nich), nijak się miała do jaszowieckiej rzeczywistości. Ku niewątpliwej konsternacji rządzących ${ }^{36}$ raport wykazał, że wzniesiono nie tyle wzorcowa

32 A. Gładysz, Wczasy..., s. 44.

${ }^{33}$ Ibidem, s. 33.

${ }^{34}$ Ibidem, s. 34.

35 Ibidem, s. 36.

${ }^{36}$ Świadectwem tego są szczególne losy publikacji przedstawiającej wyniki omawianych badań. Jak po latach wspominał jej twórca, w obliczu „niepoprawności politycznej” sformułowanych konkluzji zdecydowano się nie kierować tej niewielkiej (80 stron) książeczki, wydanej w trybie „małej poligrafii”, na rynek księgarski. Nieliczne egzemplarze, które zdołały dotrzeć do bibliotek, stanowią więc swoiste „rarytasy”. A przecież wywód był napisany ostrożnie, aprobatywnie w stosunku do ideowo-polityczno-ustrojowych pryncypiów i w retorycznych ramach przysłowiowej „konstruktywnej krytyki”... Jednak - komentował ironicznie Gładysz - „fakt, że pozwoliłem sobie twierdzić, że coś POWINNO się zmieniać na lepsze - a o tym mogła wtedy mówić tylko PARTIA - przesądził, że książka poszła na makulature”. A. Gładysz, Moje badawcze przygody w Jaszowcu, „Kalendarz Ustroński” 2001 , s. $68-71$. 
placówkę „socjalistycznych” wakacji, ile centrum trywialnego „leniuchowania” i „wczasowania towarzysko-rozrywkowego”. Najbardziej zaś w tym wszystkim irytujące (i niepokojące zarazem) było zapewne to, że opisany stan rzeczy zdawał się najzupełniej odpowiadać obywatelom (czyli faktycznym potrzebom społecznym osób wypoczywajacych) ${ }^{37}$. W istocie więc casus Jaszowca potwierdził trwającą dominację niepożądanego przez rządzących bierno-konsumpcyjnego modelu spędzania wakacji ${ }^{38}$ i ukazał wypoczynek urlopowy przeciętnego Polaka jako słabo się poddający socjalistycznemu „formatowaniu” - nawet wtedy, gdy jest ono realizowane w kontekście rozwiązań mających, jak mniemano, takowy efekt maksymalizować. Innymi słowy: Jaszowiec nie tylko unaoczniał niewygodny fakt niedostatecznej skuteczności komunistycznej inżynierii społecznej „na odcinku wczasów”, ale zdawał się stanowić dowód, że nie da się tego zmienić.

Z powyższym blisko łączyło się kolejne ideologiczne niepowodzenie: udział „prawdziwych” robotników w populacji wypoczywających pozostawał wyraźnie mniejszościowy - oscylował w granicach $20-30 \%{ }^{39}$. A przecież - paradoksalnie - w zdecydowanej większości gospodarowały tu firmy o bardzo licznych robotniczych załogach, formujacych „trzon” wielkoprzemysłowej klasy robotniczej PRL... Nawet więc w takich, najbardziej zdawałoby się sprzyjajacych, warunkach organizacyjnych Polska Ludowa nie potrafiła osiagnać tego, aby oferta wypoczynkowa oficjalnie dedykowana „klasie robotniczej”, rzeczywiście w pierwszym rzędzie trafiała do jej przedstawicieli ${ }^{40}$.

${ }^{37}$ Pokazuje to udokumentowany w omawianym badaniu fakt powtarzajacych się wysokich całościowych ocen jakości pobytu, niezależnie od często radykalnie krytycznych ocen cząstkowych w odniesieniu do omówionych wyżej kwestii ujemnych.

${ }^{38}$ Używa się tu niekiedy określenia „kolektywno-statyczny model urlopowy”. W rekonstrukcji Sowińskiego prezentuje się on następująco: „Życie wczasowe w małym stopniu podlegało wyborom, a inicjatywa należała raczej do organizatorów niż wczasowiczów. Rytm życia wyznaczały pory wydawania posiłków oraz imprezy organizowane przez personel [...]. W skrajnej postaci mogło to prowadzić do sytuacji, w której instruktor kulturalno-oświatowy decydował, o której godzinie włączyć telewizor w ośrodkowej świetlicy albo kiedy wolno pograć w karty (te dwie rozrywki należały do ulubionych). Duża część pobytu upływała na biernym wypoczywaniu, bez podejmowania większej aktywności”. P. Sowiński, op. cit., s. 113.

39 A. Gładysz, Wczasy..., s. 67-88. Później też tak było.

${ }^{40}$ Warto jednak zaznaczyć, iż współczynnik partycypowania robotników w ofercie wczasów rodzinnych w Jaszowcu i tak sytuował się powyżej średniej krajowej w tamtym czasie. Ibidem, s. 65-66. Por. R. Walicki, op. cit.; P. Sowiński, op. cit., s. 198. Wypada zreszta zauważyć, spoglądając szerzej na omawianą teraz kwestię, że nawet gdyby spełniły się nadzieje odnośnie do uzyskania w Jaszowcu wyraźnie wyższego odsetka wczasujacych robotników, to i tak sytuacja pozostawałaby bardzo odległa od zadeklarowanych, partyjno-państwowych ideałów masowego wypoczynku dla wszystkich. Z walorów kompleksu tak naprawdę korzystaliby wtedy robotnicy należący tylko do pewnej szczególnej (by nie rzec: swoiście „uprzywilejowanej”) kategorii - ci zatrudnieni w wielkich peerelowskich kombinatach. W tej perspektywie Jaszowiec obrazuje ważkie zjawisko opartego na ideologicznym kluczu rozwarstwienia i zróżnicowania społecznego, które władza komunistyczna 
Omawiany wyżej raport Gładysza wskazał, jako jedna z istotnych przesłanek utrwalenia się w Jaszowcu niepożądanego modelu wczasowania, pewien znamienny, infrastrukturalny deficyt kompleksu. Oddając do eksploatacji to nowatorskie i pod różnymi względami „zaawansowane” miasteczko rekreacyjno-wypoczynkowe, „zapomniano” (o czym już napomknąłem) zbudować na terenie doliny przewidziane w planie obiekty służące do czynnego wypoczynku, uprawiania sportów oraz zabaw dla dzieci ${ }^{41}$. Kurort naznaczony takim brakiem trudno uznawać za wzorcowy... Skądinąd fakt ten obrazował jakże charakterystyczne dla PRL zjawisko systemowej - chciałoby się rzec - niezdolności do skutecznego, pełnego finalizowania zamierzeń inwestycyjnych, szczególnie rzucające się w oczy na obszarze budownictwa dla ludności. Omalże reguła pozostawało tu nierealizowanie (albo ze znaczącym opóźnieniem) wszelkiego rodzaju obiektów „towarzyszacych” zasadniczej inwestycji, a ten relatywnie niewielki w proporcji do rozmiaru i całości kosztów danego przedsięwzięcia ubytek zwykle nieproporcjonalnie mocno ważył na finalnym efekcie. Jeśli więc Ustroń-Jaszowiec miał być „modelem” czy „wizytówka” socjalistycznego budownictwa, to w tym aspekcie stał się nim istotnie, ale w sensie na pewno przez władzę niepożądanym.

Do tego okazało się, że dopełniający część „sypialnianą” zespół obiektów centrum handlowo-usługowego nie jest dostatecznie funkcjonalny i spełnia swoje zadania w stopniu niezadowalającym - przede wszystkim dlatego, że regularne docieranie doń stawało się nazbyt uciążliwe dla większości gości domów wczasowych (za duże odległości - zwłaszcza w pionie - do pokonania). Do tego pomieszczenia klubowe oraz sklepowe były ciasne, kawiarnia i restauracja zaś w istocie zbędnie dublowały ofertę tychże domów (każdy przecież posiadał własną stołówkę oraz kawiarnię). Na domiar złego położenie wysoko na środku stoku czyniło centrum mało dostępnym dla drugiej potencjalnej grupy korzystających, czyli jednodniowych gości doliny Jaszowca. Niedostateczna pojemność kawiarni i restauracji oraz ciasnota sklepików nie pozostawały zresztą w żadnej proporcji do wielkiej liczby takowych, zainteresowanych ewentualnymi zakupami czy posiłkiem, przybyszów (w pogodne dni weekendów od wiosny do jesieni przybywały autokarami i koleją w ten rejon prawdziwe tłumy ${ }^{42}$.

intencjonalnie generowała, kierując swoje programy socjalnego wsparcia do tych przede wszystkim segmentów społeczeństwa, które uznawała za „rozwojowe”, „przodujące” i „poprawne” w perspektywie komunistycznej wizji rzeczywistości społeczno-gospodarczej.

${ }^{41} \mathrm{Z}$ rozproszonych informacji wynika, że w tym zakresie funkcjonowały w dolinie (przynajmniej okresowo) jakieś „prowizorki”, których użyteczność bywała zresztą źródłem skarg wczasowiczów. Część tych krytyk trafiała na łamy prasy lokalnej: T. Kopoczek, Superkomfort" w... zapadtej „dziurze”, „Głos Ziemi Cieszyńskiej”, 17 IV 1966, nr 16, s. 6; M. Podolska, O czym marza w Jaszowcu? Tam bytby raj..., „Trybuna Robotnicza”, 12 V 1969, nr 111, s. 3.

${ }^{42}$ Udokumentował te deficyty raport Gładysza (Wczasy..., s. 11-12). Zob. też: M. Pilch, op. cit., s. 77-78 (autor pisał m.in. na podstawie wywiadów z osobami, które były przez lata związane z kompleksem). Przez Jaszowiec przewijało się nawet 100 tys. wycieczkowiczów rocznie. 


\section{„Jednostka” vs. „system” - wzorzec czy curiosum?}

Powyższe uwagi, uwydatniające pęknięcia na obrazie funkcjonowania „kurortu z marzeń", skłaniają do uważniejszego, porównawczego spojrzenia na procesy związane z planowaniem i samą budowy kompleksu: $\mathrm{w}$ jakim stopniu rzeczywiście mógł on być modelem, „dobrym wzorem” czy pozytywnym punktem odniesienia dla reszty budownictwa wczasowego w PRL?

Nie ma wątpliwości, że zastosowana tu zasada prowadzenia planowej, skoordynowanej, całościowej inwestycji korzystnie odróżniła rozpatrywane przedsięwzięcie od „przeciętnej” w zakresie wznoszenia zakładowej bazy wypoczynkowej w komunistycznej Polsce. Dokonane za rządów Gomułki przekazanie tego pola „w ręce” zakładów pracy uwolniło wprawdzie administrację państwową od konieczności bezpośredniego nim zarządzania ${ }^{43}$, ale w dłuższej perspektywie doprowadziło do szeregu procesów patologicznych oraz marnotrawstwa. Najczęściej bywało tak, że państwowy zakład pracy występował jako podmiot samodzielnie inwestujaccy swoje fundusze socjalne w zbudowanie dla swych pracowników ośrodka/ domu wczasowego - obiektu na miarę finansowych i organizacyjnych możliwości danej firmy, ulokowanego „tam gdzie się uda” w obrębie obszarów przeznaczanych pod zabudowę turystyczno-rekreacyjna. Nierzadko budynki wznoszono na poły legalnie, co w PRL znaczyło: poza planem, tzn. z wykorzystaniem siły roboczej oraz materiałów przeznaczonych (i faktycznie zwykle potrzebnych) na coś innego.

[Zakładowe] budownictwo turystyczne do pewnego stopnia wyłamywało się z jakiejkolwiek kontroli. [Już] w latach 60. - pisał Sowiński - pojawiło się na szerszą skalę zjawisko na wpół dzikich inwestycji stawianych z pominięciem planów zagospodarowania terenu i z naruszeniem obowiąujących przepisów, a także lokalnych tradycji budowlanych. [...] Budowniczowie ośrodków wczasowych wznosili je w godzinach pracy, z państwowych materiałów i na zasadzie priorytetu. Aby zakamuflować zasięg tych prac, kwalifikowano je nieraz jako czyn społeczny. Nie oglądając się na koszty, przewożono materiały (i ludzi) z własnych zapasów do odległych czasem o kilkaset kilometrów terenów budowy ${ }^{44}$.

${ }^{43}$ Przede wszystkim zaś umożliwiło nowe inwestycje bez konieczności (a to było chyba kluczowe) angażowania środków bezpośrednio pozostających w jej dyspozycji. W ramach swojej wewnętrznej gospodarki finansowej środkami obrotowymi zakłady pracy mogły bowiem wydzielać specjalne fundusze na potrzeby socjalne swych pracowników, w tym zwłaszcza na rozwój wypoczynku. Przepisy i wytyczne na temat zasad tworzenia funduszu socjalnego oraz zasad gospodarowania nim były zresztą bardzo powikłane i wielokrotnie się zmieniały na przestrzeni lat 1945-1989. Wszystko to ułatwiało firmom, zwłaszcza tym bogatszym, dość swobodne (nawet jeśli półlegalne) wydatkowanie naprawdę sporych środków na budowę obiektów wypoczynkowych. Na temat ewolucji tych przepisów zob. R. Okrasa, Organizacja, finansowanie i formy wczasów pracowniczych, Warszawa 1988, s. 54-77; idem, Wczasy..., s. 94-98.

${ }^{44}$ P. Sowiński, op. cit., s. 139, 125. Na samodzielnie budowy „porywały się” firmy reprezentujące najróżniejsze gałęzie wytwórczości (a także handel i usługi), bardzo nieraz odległe od sfery jakkolwiek bądź rozumianego budownictwa. 
Tacy wpływowi inwestorzy często zakłócali lokalne stosunki ${ }^{45}$ i arogancko „rozpychali się” na obszarach przeznaczanych pod turystykę oraz wypoczynek ${ }^{46}$.

W dolinie Jaszowca sprawy przebiegły inaczej. W roli wiodacego organizatora przedsięwzięcia wystapiła administracja państwowa szczebla wojewódzkiego, która oficjalnie „zaprosiła” do udziału w nim zainteresowane firmy z terenu całego kraju ${ }^{47}$ wtedy dopiero, gdy już określono lokalizację inwestycji i zatwierdzono architektoniczny projekt całości jako zintegrowanego stylistycznie oraz funkcjonalnie kompleksu, który - obok nieruchomości wczasowych we władaniu poszczególnych inwestorów ${ }^{48}$ - posiadać będzie szereg elementów wspólnych. I to nie owe firmy/ inwestorzy, ale podległe administracji, specjalnie do tego celu powołane agendy pilotowały całe przedsięwzięcie i sprawowały nad nim nadzór. Inwestorzy, zasadniczo rzecz biorąc, po prostu przekazali swe finansowe udziały do „wspólnej puli” środków, które posłużyły do sfinansowania w sposób kompleksowy wieloskładnikowej inwestycji realizowanej w całości przez jeden podmiot wykonawczy reprezentujący odpowiednią (czyli budowlana) branżę ${ }^{49}$. Nie ma chyba wątpliwości, że tego typu rozwiązanie stanowiło warunek niezbędny do pomyślnego wykonania

45 „Poszczególni inwestorzy, martwiąc się jedynie o swój teren, podłączali się do kolektorów kanalizacyjnych, urządzeń wodociągowych, gazowych i elektrycznych, powodując szybkie ich przeciążanie, utrudniając korzystanie z wody, światła i gazu zarówno sobie nawzajem, jak i stałym mieszkańcom miejscowości turystycznych. Nikt z inwestorów nie dbał o interesy publiczne, o budowę usług, sklepów, miejsc rozrywki”. H. Gurjanowa, B. Jałowiecki, Przestrzenno-społeczne zagadnienia organizacji wypoczynku, Warszawa 1972, s. 99. Przytoczony passus bezpośrednio dotyczył sytuacji w kurortach nadmorskich, ale w gruncie rzeczy opisywał stan rzeczy napotykany niemal wszędzie na przełomie lat sześćdziesiątych i siedemdziesiątych, a także później.

46, „...] dynamicznie rozwijane budownictwo zakładów pracy zajmowało najlepsze tereny [...], co w systemie komunistycznym oznaczało ich trwałe wyłączenie z powszechnego użytku. [...] kombinaty i zjednoczenia przemysłowe rugowały z najlepszych terenów mniej znaczących organizatorów wypoczynku, nie tylko lepiej płacąc na przykład za wynajem, ale także świadcząc różne usługi na rzecz okolicznej ludności”. P. Sowiński, op. cit., s. 229.

${ }^{47} \mathrm{Na}$ potrzeby sfinansowania projektu zawiązano specjalne konsorcjum 16 zainteresowanych podmiotów gospodarczych. Dominowały oczywiście te z województwa katowickiego, ale przyłączyły się też m.in. płocka Petrochemia i puławskie „Azoty”, pomijając już takie ogólnokrajowe kolosy, jak PKP czy Lasy Państwowe.

${ }^{48}$ Ostatecznie firmy należące do resortu przemysłu wydobywczego (zjednoczenia górnictwa węglowego i/lub konkretne kopalnie) władały trzema „liniowcami” i trzema „wielotraktowcami”, zakłady przynależne resortowi przemysłu chemicznego miały po jednym obiekcie w każdej z trzech głównych kategorii, przedsiębiorstwa podległe Ministerstwu Budownictwa prowadziły zaś dwa „gronowce” oraz „wielotraktowiec”. Po jednym obiekcie miały Lasy Państwowe (,gronowiec”), Polskie Koleje Państwowe (,wielotraktowiec”), Poczta Polska (,pseudoliniowiec”), resort oświaty (,jednoliniowiec” zarządzany za pośrednictwem Zwiazku Nauczycielstwa Polskiego) oraz Huta Pokój (obiekt przedwojenny).

${ }_{49}$ Budowę prowadziło Przedsiębiorstwo Budownictwa Miejskiego w Bielsku pod finansowym nadzorem Dyrekcji Budowy Osiedli Robotniczych w Tychach. Agenda zajmującą się koordynacją i nadzorem była wspomniana już wcześniej Komisja Koordynacyjna. 
projektu tak całościowo pomyślanego, tak realizacyjnie złożonego i do tego obiecującego „nowa jakość” w zakresie możliwości spędzania urlopu wakacyjnego. Poprzedzający inwestycję etap wszechstronnego planowania pozwalał też liczyć na to, że kompleks nie będzie - jak to często się zdarzało w miejscowościach wypoczynkowych - „pasożytował” na przeciaż̇onej miejscowej infrastrukturze komunalnej. W pewnym stopniu tak się rzeczywiście stało ${ }^{50}$, niemniej jednak pojawienie się $\mathrm{w}$ granicach Ustronia całego wczasowego miasteczka wygenerowało problemy dla miejscowych władz. Bardzo wydatnie bowiem powiększyło wyzwanie (i tak już endemicznie trapiące w PRL wszystkie miejscowości wypoczynkowe) skutecznego zaspokajania potrzeb dodatkowej, dużej liczby osób, których z reguły nie uwzględniały należycie w swoich „rozdzielnikach” oraz „przydziałach” centralne plany przygotowywane w warszawskich ministerstwach i radach wojewódzkich ${ }^{51}$.

W tej perspektywie zatem można chyba mówić o Jaszowcu jako sukcesie, a nawet swego rodzaju ,ideale” na tle obserwowanego w PRL chaosu wypoczynkowych inwestycji indywidualnych przedsiębiorstw, zjednoczeń czy branż. Czy jednak wolno było widzieć w nim „wzorzec” możliwy - jak głosiła propaganda - do naśladowania gdzie indziej? To już wydaje się wątpliwe. Raczej należałoby przyjać, że w swej szczególnej postaci kompleks zaistniał dlatego (może wręcz: wyłącznie dlatego), że w toku przygotowywania oraz prowadzenia inwestycji udało się „przełamać” - „lokalnie” co prawda i na krótki czas - pewne fundamentalne i strukturalne zarazem ograniczenie peerelowskiego modelu zarządzania oraz gospodarowania, tj. „resortowość” ${ }^{2}$.

${ }^{50}$ Budowa Ustronia-Jaszowca była przesłanką dla godnych uwagi postępów w zakresie robót gazyfikacyjnych w Ustroniu, inwestycji w zakresie dróg lokalnych itd. H. Lipowczan, op. cit., s. 21; G. Sztwiertnia, op. cit., s. 628.

${ }^{51}$ Ogólnie na temat regularnie nawracających zakłóceń gospodarczych wywoływanych w takich miejscowościach przez sam fakt nastania sezonu urlopowego i napływu gości (spotęgowane niedobory towarowe, zachwianie na rynku pracy, przeciążenie nieelastycznego państwowego systemu transportu, handlu i gastronomii) oraz „syzyfowych” wysiłków, za pomocą których lokalna władza starała się zwalczać takie trudności, zob. P. Sowiński, op. cit., s. 107-109. Bardziej szczegółowo i bezpośrednio w odniesieniu do interesującej nas miejscowości w latach sześćdziesiątych i siedemdziesiątych zob. D. Malczewska-Pawelec, T. Pawelec, Akcja „lato”. Peerelowskie uzdrowisko przygotowuje się do sezonu (na przyktadzie Ustronia), w: Tradycje $i$ perspektywy rozwoju kultury uzdrowiskowej w Iwoniczu-Zdroju w kontekście europejskim, red. B. Płonka-Syroka, A. Kaźmierczak, S. Jandziś, A. Syroka, Wrocław 2018, s. 341-362; A. Michałek, Życie gospodarcze 1945-1989, w: Ustroń..., t. II, s. 714.

${ }^{52}$ Naturalnie zjawisko „złej resortowości”, tzn. permanentnego sporu kompetencyjnego pomiędzy agendami administracji oraz irracjonalnej „rywalizacji” poszczególnych resortów w obliczu nakładania się i/lub kolizji wyznaczonych im zakresów działania, nie jest charakterystyczne tylko dla PRL (czy szerzej państwa komunistycznego). Tutaj jednak, m.in. skutkiem „przeplatania się” aparatu państwa oraz aparatu partii komunistycznej (faktycznie posiadającego kompetencje władczo-kontrolne względem tego pierwszego na każdym szczeblu decydowania), stopień zawiłości struktur zarządzających pozostawał szczególnie wysoki, a generowany tym chaos i niedowład decyzyjny - szczególnie uderzające. Ogólnie 
Nie tylko chodziło o fakt, że konsorcjum inwestorów konstytuowały firmy podlegające różnym ministerstwom, ale i o to, że sam proces planowania oraz realizowania inwestycji przebiegał - jak to widzieliśmy - niezależnie od resortowych afiliacji/ ograniczeń/ możliwości ich wszystkich ${ }^{53}$.

Takie niestandardowe wyjście z resortowych „kolein” było swoistym ewenementem i stało się możliwe dzięki szczególnej konfiguracji personalnej na szczytach władzy w stolicy województwa katowickiego. Znalazła się tam konkretna, wielce wpływowa osoba, wykazująca wysoki poziom czynnego zainteresowania projektem Jaszowca i stale mu patronujaca - Jerzy Ziętek, wiceprzewodniczacy, a od 1964 przewodniczacy Wojewódzkiej Rady Narodowej (WRN) w Katowicach ${ }^{54}$. To było kluczowe, ponieważ w realiach

o zagrożeniach i dysfunkcjach „resortowości” zob. P. Dąbrowski, Resortowość jako źródto zagrożeń w systemie zarzadzania kryzysowego, „Prace Geograficzne” 2014, t. LV, s. 19-26.

53 „Resortowość” powróciła zresztą do Jaszowca zaraz po zakończeniu budowy. Każdy dom wczasowy stał się zupełnie odrębnym podmiotem, zarządzanym i finansowanym wedle konkretnych, w dużej mierze przez resortowe podległości zdefiniowanych, preferencji czy możliwości poszczególnych właścicieli. Skutkowało to znaczącymi różnicami w stawce żywieniowej dla gości, mniej lub bardziej bogatym wyposażeniem pokoi, odmienną atrakcyjnością programu pobytu w domach, które wizualnie/ konstrukcyjnie/ architektonicznie jawiły się jako zupełnie porównywalne. Od początku (co od razu uchwycił raport Gładysza) generowało to szereg napięć w obrębie populacji wczasowiczów, które musiały wpływać na odczuwaną przez nich satysfakcję z wypoczynku. Podobny efekt wystapił w odniesieniu do zatrudnionego w domach personelu - różnica stawek za ten sam zakres świadczonej pracy oraz odmienny poziom obciążenia obowiązkami (uboższy właściciel realizował porównywalne zadania mniejszą liczba gorzej opłacanych pracowników) powodowały konflikty i fluktuację zatrudnienia. W tym kontekście zwracały uwagę dodatnie efekty utrzymanych w obrębie doliny rudymentów wspólnego zarządzania, pod postacią działań Zakładu Obsługi Jaszowca (wydzielonej jednostki w ramach Miejskiego Przedsiębiorstwa Gospodarki Komunalnej w Ustroniu, majacej „utrzymywać wspólne urządzenia komunalne” kompleksu i świadczyć na rzecz poszczególnych domów usługi remontowe, transportowe oraz pralnicze) oraz Międzypowiatowego Domu Kultury (funkcjonował w pomieszczeniach klubowych centrum handlowego). Zwłaszcza ta ostatnia placówka, wspólnie finansowana w proporcji do wielkości poszczególnych domów wypoczynkowych, działająca zarówno na rzecz wczasowiczów, jak i stałych mieszkańców południowej części Ustronia, mimo niekorzystnych warunków lokalowych i ograniczeń organizacyjnych rozwinęła z czasem dość intensywna, owocną działalność. Więcej na ten temat zob. A. Gładysz, Wczasy..., s. 9-12; L. Szkaradnik, M. Żyromski, Przejawy aktywności kulturalnej w Ustroniu po 1945 r., w: Ustroń..., t. II, s. 205; APK OC, PMRNU 1969, 56 (prot. 5 z 5.08.69); APK OC, PMRNU 1970, 57 (prot. 20 z 3.03.70). Do prób stworzenia wspólnej struktury zarządzającej powrócono u schyłku lat osiemdziesiątych, gdy - jeszcze w ramach systemu komunistycznego - szukano sposobów i środków na rewitalizację dekapitalizującego się już Jaszowca. L. Szkaradnik, Od gminnej do miejskiej..., s. 62.

${ }^{54} \mathrm{~W}$ ówczesnych realiach były to funkcjonalne odpowiedniki stanowisk wicewojewody oraz wojewody. Najpełniejsze studium postaci Ziętka: J. Walczak, Jerzy Ziętek. Biografia Ślazaka (1901-1985), Katowice 2002. Ponieważ autor pisał nie bez akcentów apologetycznych i pomijania pewnych niekorzystnych dla bohatera aspektów jego działalności w PRL, opracowanie warto konfrontować z wydaną niedawno publikacją Instytutu Pamięci Narodowej: 
gospodarki komunistycznej i właściwego dla niej chaosu oraz niedowładu decyzyjno-organizacyjnego najlepsza gwarancję efektywnej realizacji oraz finalnego powodzenia danego przedsięwzięcia stanowiła właśnie życzliwa uwaga kogoś takiego. Inwestycje - choćby nawet już zaakceptowane i „wstawione do planu” - zwykle wymagały dalszego, nieustannego „popychania” przez decydenta osobiście zainteresowanego ich pomyślnym, terminowym zrealizowaniem. Skądinąd w wypadku Jaszowca decydujące okazały się nie tyle standardowe techniki „popychania” ${ }^{55}$, ile forma bardziej „wysublimowana", polegajacca na wprowadzeniu - z racji swojej zwierzchniej i władczej pozycji - nadzwyczajnych (niekoniecznie zawsze do końca sformalizowanych czy prawomocnych) rozwiązań organizacyjno-instytucjonalnych służących optymalizacji przebiegu danego przedsięwzięcia. To właśnie Ziętek stał za ustanowieniem całej tej wyżej opisanej, skutecznej formuły przeprowadzenia

\footnotetext{
A. Dziuba, A. Dziurok, B. Linek, B. Tracz, D. Węgrzyn, Jerzy Ziętek. Konteksty kariery $w$ komunistycznym państwie, Katowice 2018. Ziętek był postacią niewątpliwie szczególna i godna badawczej uwagi: (1) stanowił zupełnie wyjątkowy przykład udanego transferu z grona piłsudczykowskich ludzi władzy doby międzywojnia do kręgu najwyższych elit przywódczych Polski Ludowej; (2) na tle ogólnie niskiego poziomu peerelowskiego zarzadzania wyróżniał się jako relatywnie skuteczny, pragmatyczny administrator. Stało się to później punktem wyjścia do intensywnego kreowania w Katowicach swoistego mitu czy „legendy” Ziętka jako „apolitycznego” (choć przecież dostapił on z czasem nawet członkostwa w Komitecie Centralnym PZPR), fachowego państwowca i dobrego gospodarza w regionie przez środowiska lewicowe i postkomunistyczne w ramach walki o „dobra pamięć” (sic!) czasów PRL. Szerzej zob. B. Tracz, Ślazak - żotnierz - gospodarz. Jerzy Ziętek jako przykład mitologizacji politycznej, w: A. Dziuba, A. Dziurok, B. Linek, B. Tracz, D. Węgrzyn, op. cit., s. 40-51. Sprawa wiodących zasług Ziętka w powstaniu Jaszowca stanowi naturalnie znaczący komponent tej opowieści.

${ }_{55}$ Należały do nich nasilone indagowanie/ monitorowanie odpowiedzialnych za przedsięwzięcie co do przebiegu oraz postępu prac ramach posiadanych uprawnień kontrolnych i zwierzchnich oraz rozmaite mniej lub bardziej formalne interwencje w stosunku do instytucji i osób, które swymi działaniami/ zaniechaniami spowalniały czy blokowały postęp robót. Naturalnie również i z takich form Ziętek nie wahał się korzystać w przypadku Jaszowca: „[...] pilnie doglądał postępu prac - czytamy przykładowo w jednym ze wspomnień - Poruszał wszystkie sprężyny w celu zdobycia środków i materiałów. Był niezmordowany. Ludzie [...] pamiętaja, że narady na budowie o piątej rano nie były niczym dziwnym. Trafiały się też sztabówki o drugiej w nocy. Zawsze i wszędzie - mimo poważnie zaawansowanego wieku - zadziwiał bystrościa, rzeczowością i precyzyjnością". W. Gołkowski, Generał czynu, „Kalendarz Ustroński” 2000, s. 143. Materiały Sekretariatu Jerzego Ziętka w zespole akt Prezydium WRN w Katowicach (APK, PWRNK, 12/224/0/1.1/1-164) zawieraja bardzo wiele teczek dokumentujacych przypadki osobistego „przepychania” także innych spraw i przedsięwzięć, na których istotnie mu zależało. Część z nich opisano w biografii. J. Walczak, op. cit., passim. Zainteresowanie Ziętka Jaszowcem (i w ogóle sprawami turystyczno-uzdrowiskowego rozwoju Wisły i Ustronia) cały czas opisywała ówczesna prasa regionalna. Niekiedy artykuły na ten temat sygnowane były jego nazwiskiem. Zob. m.in.: Płk. Jerzy Ziętek zainteresowany rozwojem ustrońskiego uzdrowiska, „Głos Ziemi Cieszyńskiej”, 10 III 1960, nr 9, s. 3; J. Ziętek, Znaczenie rozbudowy Ustronia $i$ Wisty, „Głos Ziemi Cieszyńskiej”, 27 III - 2 IV 1959, nr 13, s. 3; idem, Budowa największej w kraju inwestycji wczasowej...
} 
inwestycji, z Wojewódzką Komisją Koordynacyjną jako organem zarządzającym i swoja własna osoba na jej czele ${ }^{56}$. Był to zreszta wariant czy konkretyzacja rozwiązań, które właśnie - nie bez sukcesu - wprowadzał na szerszym polu zarządzania budownictwem mieszkaniowym w regionie ${ }^{57}$. Konfrontowany tam $\mathrm{z}$ wyzwaniami naprawdę poważnymi ${ }^{58}$, zareagował w opisanym, charakterystycznym dla siebie stylu. By podnieść tempo oraz jakość budowy mieszkań (co do pewnego stopnia faktycznie się udało), przełamawszy resortowe podległości, skupił pod zarządem władz wojewódzkich w Katowicach (tzn. Prezydium WRN, a w praktyce swoim własnym) wszystkie podmioty/ przedsiębiorstwa zajmujące się budownictwem na potrzeby ludności. W ten sposób, likwidując pionowe (branżowe) zależności, administracyjnie stworzył rodzaj swoistego holdingu czy konglomeratu firm kontrolującego całokształt procesów wznoszenia domów i całych osiedli mieszkaniowych: planowanie/ projektowanie, wykonawstwo łącznie z „wykończeniówką” oraz transport budowlany. Zorganizował tu szereg wyspecjalizowanych organów zarządzających, w rodzaju Wojewódzkiego Zarządu Projektowania Budownictwa, Wojewódzkiego Zrzeszenia Biur Projektowych, Ślaskkiego Zarządu Budownictwa Miejskiego, Wojewódzkiej Pracowni Urbanistycznej i innych. „Obok oficjalnych struktur organizacyjnych - pisał jego biograf - powoływał ciała pozastatutowe. Chętnie tworzył organa doraźne. Każdy z tych elementów miał określone zadania do

56 Wiązało się to ze szczególnym paternalistycznym rysem naznaczającym aktywność Ziętka jako urzędnika administracji publicznej już od przedwojennej funkcji Naczelnika Gminy Radzionków, którą to właściwość jego biograf niewątpliwie przekonująco udokumentował. Jej sednem było zaabsorbowanie szeroko rozumianymi sprawami bytowymi ludności na podlegajacym jego władzy terenie, połączone $\mathrm{z}$ talentem do wynajdowania niestandardowych rozwiązań w obliczu zaistniałych w tym zakresie wyzwań i problemów oraz z gotowościa do przełamywania barier finansowych i organizacyjnych - choćby nawet działaniami na granicy prawa i wbrew zastanej pragmatyce urzędowej. Realia PRL, wszechstronnie uprzedmiotawiającego społeczeństwo jako bierny obiekt zabiegów, „opieki” i „troski” ludowej władzy, otwierały spore przestrzenie do działania w ramach takiego paternalistycznego podejścia, o ile podejmowane przedsięwzięcia udawało się wpisywać w dominujące trendy i formuły ideologiczne. Jerzy Ziętek to potrafił, umiał też na rzecz swych planów i zamierzeń skutecznie lobbować w kręgach decydentów wyższego szczebla.

57 Ziętek realnie kierował tymi działami administracji publicznej, które były „niepriorytetowe” ideologiczno-politycznie, ale za to istotne dla jakości życia mieszkańców województwa. Należały do nich administracja państwowa w terenie, gospodarka komunalna, planowanie regionalne, ochrona zdrowia ludności, mieszkalnictwo (łącznie $\mathrm{z}$ budownictwem mieszkaniowym), szkolnictwo, kultura oraz wypoczynek i turystyka. Oczywiście „ostatnie słowo” - w ramach „kierowniczej roli PZPR” - należało zawsze do Komitetu Wojewódzkiego (KW), ale urzędujący do 1970 r. w Katowicach jako I sekretarz KW Edward Gierek niemal zawsze „żyrował” jego plany i decyzje.

${ }^{58}$ Ogólnokrajowy głęboki niedostatek izb mieszkalnych drastycznie potęgowany był na terenie województwa katowickiego poprzez demograficzne efekty forsowanej w regionie industrializacji - to właśnie na Górny Śląsk i do Zagłębia Dąbrowskiego napływały ściagane zewsząd do pracy w przemyśle ciężkim oraz wydobywczym dziesiątki tysięcy młodych ludzi, którzy musieli gdzieś zamieszkać. 
wykonania, nad nimi czuwały pośrednie organa koordynacyjne, a ten złożony system wieńczył sam Ziętek" 59 . Powyższe należy rozumieć dosłownie: wraz z niewielkim gronem najbliższych współpracowników rzeczywiście na bieżąco kontrolował pracę wymienionych struktur, zawarowując dla siebie zasadnicze decyzje $^{60}$. Jest jasne, że ten „woluntarystyczny” w swojej naturze (by użyć nowomowy tamtej epoki) model managementu dalece odbiegał od oficjalnych reguł planowego „socjalistycznego gospodarowania”"61. Wykazywał jednak skuteczność, co uwidoczniło się także przy budowie Jaszowca ${ }^{62}$.

W sumie więc status rozpatrywanego przypadku okazuje się złożony i niejednoznaczny. Z jednej strony wznoszony w opisanym trybie Ustroń-Jaszowiec na pewno nie kwalifikował się do miana wzorcowej socjalistycznej budowy. Właściwie nawet wypadałoby mówić o zaistnieniu tu „antywzorca” - i to naprawdę ideologicznie kłopotliwego dla rządzących $\mathrm{z}$ racji zademonstrowanej realizacyjnej efektywności... Z drugiej jednak strony należy widzieć $\mathrm{w}$ nim przykład o charakterze rzeczywiście modelowym $\mathrm{w}$ takim oto sensie, że ukazywał się tu prawdziwy (w sensie zgodności z realną praktyka

59 J. Walczak, op. cit., s. 354. Szczegółowy opis tej „śląskiej autonomii budowlanej” zob. ibidem, s. 349-364.

${ }^{60}$ Wnioskuję, iż to właśnie osobisty udział najwyższego zwierzchnika zapobiegał narastaniu w obrębie tej szczególnej całości kompetencyjnego chaosu i decyzyjnego paraliżu. $\mathrm{Z}$ niewątpliwą przesadą porównywano Ziętkowe metody zarządzania do modelu działania menedżerów wielkich amerykańskich korporacji. Ibidem, s. 355-357.

${ }^{61}$ Choć naturalnie dokumenty sporządzane w Prezydium WRN i w KW PZPR sugerowały coś przeciwnego. Taki sposób zarządzania, będąc jawnym odstępstwem od wspomnianych reguł, paradoksalnie pozostawał jednocześnie koniecznym ich uzupełnieniem. Nierzadko bowiem tylko w drodze „ręcznego sterowania” dawało się „rozcinać” pojawiające się raz po raz kolejne „gordyjskie węzły” zarządzania gospodarką niedoboru czy spowitym siecią ideologii oraz partyjnej kontroli państwowym aparatem administracyjnym.

${ }^{62}$ Skuteczność tego modelu zależała jednak od obecności w newralgicznym punkcie dostatecznie zręcznego sternika, inaczej chaos, bezwład i brak efektywności działań mogłyby tylko narastać. Tak właśnie było w opisywanym przypadku, ufundowanym na szczególnej kombinacji umiejętności menedżerskich oraz dynamiki kariery życiowej Jerzego Ziętka. Dzieje gospodarcze PRL „zaludnia” liczny zastęp takich - mniej czy bardziej prominentnie umiejscowionych w strukturze władzy - „ręcznych sterników” gospodarczych oraz administracyjnych, bardzo zróżnicowanej zresztą „jakości”. Wydaje się, że programowe (i na różnych poziomach ogólności) rozpatrywanie przemian oraz funkcjonowania peerelowskiej ekonomiki przez pryzmat ich (quasi?)-racjonalnych decyzji stanowiłoby pożyteczne uzupełnienie ujęć bardziej systemowych czy strukturalnych, jakże często „odhumanizowanych” czy nawet „odhistorycznionych”. Znamienne jest również to, że „wewnątrzsystemowe” krytyki socjalistycznego zarządzania, gospodarowania i rozwoju, generowane w peerelowskich elitach władzy w kontekście „potykania się” o kolejne kryzysy, tak często podnosiły problem „woluntaryzmu” decyzji oraz działań krytykowanej na danym etapie ekipy rządzącej... Zob. np.: J. Topolski (występujący tym razem raczej w roli partyjnego eksperta niż dziejopisarza), Metodologia badania źródet kryzysów społecznych, w: idem, Historia i życie, Lublin 1988, s. 147-175; idem, Refleksje historyka w zwiazku z wydarzeniami lipca-września 1980 roku, w: idem, Historia $i$ życie..., s. 176-197. 
i pragmatyką działania w PRL, nie zaś z ideologicznymi postulatami czy „zadekretowanym” formalnym stanem prawno-organizacyjnym) obraz tego, jak faktycznie wyglądało realizowanie inwestycji - nie tylko zreszta tych o charakterze wczasowym - w dobie Polski Ludowej.

\section{Podsumowanie: Ustroń-Jaszowiec i PRL (oraz post mortem)}

Prowadzone na kartach niniejszego studium rozważania pokazały, jak geneza wczasowego miasteczka w Ustroniu, jego powstawanie i późniejsza działalność uwidaczniają rozmaite właściwości PRL, w szczególności zaś fundamentalny, wielopostaciowy i wielowymiarowy rozziew pomiędzy obowiązująca ideologia „ludowego" państwa a realiami funkcjonowania zarówno agend samej władzy komunistycznej, jak i kontrolowanej przez nią zbiorowości mieszkańców Polski. W skrócie mówiąc, casus Ustronia-Jaszowca - którym nota bene partyjno-państwowe kierownictwo województwa katowickiego naprawdę się w swoim czasie szczyciło - skutecznie obrazuje, jak rzeczywiście układały się sprawy w PRL. Niczym w soczewce skupia się tu szereg funkcjonalnych antynomii oraz „niemożności” ówczesnego państwa i społeczeństwa, ale zarazem widać wysiłek (i zwyczajnych ludzi, i niektórych bodaj partyjno-państwowych administratorów), aby „jakoś sobie radzić” w tamtych naznaczonych ideologia komunistyczną czasach. W tym sensie wolno chyba widzieć w Jaszowcu swoista miniaturę peerelowskiej Polski.

O głębokim (by nie rzec „intymnym”) związku rozważanego kompleksu z miniona już epoka „realnego socjalizmu” zaświadcza coś jeszcze - dynamika losów Jaszowca po ustrojowej transformacji. Kombinat, dostosowany do specyficznego, zamkniętego systemu państwowego wypoczynku dla mas, nie miał szans jej przetrwać ${ }^{63}$. Nowa epoka przyniosła więc radykalna dezintegrację zespołu jako funkcjonalnej całości. Rychło ruszyły przekształcenia własnościowe, które przybrały charakter żywiołowy i „rozproszony”, tzn. poszczególne fragmenty całości prywatyzowano oddzielnie - w różnym czasie, z udziałem odrębnych inwestorów/ nabywców i bez troski o cała resztę. W pierwszym rzędzie poskutkowało to zatratą większości elementów wspólnych, pozostawionych jako „bezpańskie” (czy - ściślej mówiąc - „na łasce” samorządu gminnego Ustronia). Najbardziej uderza to w odniesieniu do architektury krajobrazu, z której ocalały jedynie fragmenty bezpośrednio przylegające do poszczególnych domów wczasowych (tych spośród nich, które nadal funkcjonuja) oraz główny trakt spacerowy konserwowany (a obecnie rewitalizowany) przez władze miasta. Na miejscu przychodni wyrósł duży prywatny apartamentowiec, w podobnego rodzaju obiekt obrócono też

${ }^{63}$ Szkic do obrazu „zderzenia się Jaszowca” z gospodarką rynkową nakreśliła Alicja Michałek. A. Michałek, Życie gospodarcze 1989-2005, w: Ustroń..., t. II, s. 731-733. 
z czasem dawne centrum handlowo-usługowe, które zresztą nieomal zdążył już pochłonąć las ${ }^{64}$. Część domów upadła (nawet bezpowrotnie), niektóre - źle zarządzane - z trudem wegetuja. Inne, sprywatyzowane szczęśliwiej bądź zachowujące jakaśs instytucjonalną więź z dawnym właścicielem, poradziły sobie na zupełnie odmienionym rynku usług wypoczynkowych i sanatoryjnych, ewentualnie zaistniały na niwie szkoleń/ konferencji lub opieki społecznej dla osób w podeszłym wieku. Remonty i przebudowy, dostosowujące je do nowego modelu funkcjonowania, wydatnie zazwyczaj podniosły ich standard, po części zacierajacc przy tej okazji ich pierwotne architektonicznie powinowactwo. W dolinie Jaszowca nie ma już niezwykłego miasteczka wczasowego, wciąż jednak obecny pozostaje ślad minionej, peerelowskiej przeszłości.

\section{Streszczenie}

Artykuł traktuje o powstaniu wczasowego miasteczka Jaszowiec w Ustroniu, które stanowiło wyjątkową w dziejach PRL próbę zrealizowania w praktyce marzenia o wzorcowym, idealnym socjalistycznym kurorcie. Rezultat był pod niektórymi względami naprawdę imponujący, ale równocześnie okazał się fundamentalnym niepowodzeniem w perspektywie celu zasadniczego. Dlatego sprawa Jaszowca nadaje się na szczegółowe case study odnośnie do założeń oraz rozwiązań kształtujących/ wyrażających politykę komunistów w zakresie zarządzania masowym wypoczynkiem ludności w skali kraju. Miast bowiem ziścić sen peerelowskich decydentów, kombinat nieoczekiwanie uwydatnił utopijność i dysfunkcjonalność przesłanek, z jakich oni wychodzili oraz strategii, które realizowali.

Autor podejmuje namysł nad komunistycznym ideałem wypoczynku dla mas oraz ramami organizacyjnymi zbiorowego wypoczynku w komunistycznej Polsce, z których wyrastały założenia Jaszowca. Rozpatrując zasadnicze momenty planowania oraz realizacji projektu, identyfikuje szereg jego właściwości uchwytnych w trakcie budowy, jak też manifestujących się później w jego architekturze oraz organizacyjnych ramach i formułach działalności. Odnosząc powyższe do ogólnych realiów funkcjonowania gospodarki i społeczeństwa PRL, rozpoznaje zasadnicze pęknięcia i wewnętrzne sprzeczności, jakimi naznaczone było to przedsięwzięcie. $\mathrm{Na}$ tej podstawie identyfikuje i rekonstruuje mechanizmy oraz przesłanki ideologicznego niepowodzenia analizowanej próby, zarazem wskazując i tłumacząc przestrzenie ograniczonego (ale realnego) sukcesu Jaszowca jako wypoczynkowej propozycji dla mieszkańców PRL. Ukazuje go jako swoisty „antywzorzec” socjalistycznej budowy (ideologicznie kłopotliwy dla rządzących z racji zademonstrowanej realizacyjnej efektywności), a jednocześnie jako przykład modelowy, tzn. ukazujący prawdziwy (w sensie zgodności z ówczesna realną praktyka i pragmatyką działania, nie zaś z ideologicznymi postulatami czy „zadekretowanym” formalnym stanem prawno-organizacyjnym) obraz tego, jak faktycznie wyglądało realizowanie inwestycji - nie tylko zreszta tych o charakterze wczasowym - w dobie Polski Ludowej. Rozważania pokazuja, jak geneza miasteczka wczasowego, jego powstawanie i późniejsza działalność uwidaczniają rozmaite właściwości PRL, w szczególności zaś fundamentalny rozziew pomiędzy obowiąująca ideologią „ludowego” państwa a realiami funkcjonowania zarówno agend władzy komunistycznej, jak i kontrolowanej przez nią zbiorowości mieszkańców Polski. Casus Ustronia-Jaszowca niczym w soczewce skupia szereg funkcjonalnych

${ }^{64}$ Obraz jego ruiny w końcu lat dziewięćdziesiątych opisywano w prasie. Wizytówka uzdrowiska, „Głos Ziemi Cieszyńskiej”, 29 V 1998, nr 22, s. 7. 
antynomii oraz „niemożności” ówczesnego państwa i społeczeństwa, ale zarazem pokazuje wysiłek (zwyczajnych ludzi i niektórych bodaj partyjno-państwowych administratorów), aby „jakoś sobie radzić” w tamtych naznaczonych ideologia komunistyczną czasach. W tym sensie stanowi swoistą miniaturę peerelowskiej Polski.

\section{Ustron-Jaszowiec. Unfulfilled Dream about a Socialist Resort (from Studies on the Culture of Holidays and Leisure in the Polish People's Republic)}

The article presents the establishment of the holiday town of Jaszowiec in Ustron, which was a unique attempt in the Polish People's Republic to achieve the dream of a model, ideal socialist resort. In some respects, the result was truly impressive, but at the same time, it was a fundamental failure in terms of the primary intention. Instead of making the communist decision-makers' dreams come true, the resort unexpectedly highlighted the utopianism and dysfunctionality of the premises from which they started and the strategies they implemented. Therefore, the Jaszowiec case is suitable for a detailed case study of the assumptions and solutions shaping/expressing the communist policy on the management of mass recreation on a national scale.

The author reflects on the communist ideal of leisure for the masses and the organisational framework of collective relaxation in communist Poland, from which the assumptions of Jaszowiec grew. Analysing the crucial moments of planning and the implementation of the project, he identifies a number of its characteristics, evident during its construction and manifesting later in its architecture and organisational framework and formulas of activity. Referring the above to the general realities of the economy and society of the Polish People's Republic, he identifies the fundamental cracks and internal contradictions that marked this undertaking. On this basis, he identifies and reconstructs mechanisms and premises of the ideological failure of the analysed attempt, at the same time indicating and explaining areas of limited (but real) success of Jaszowiec as a leisure design for inhabitants of Poland. He shows it as a kind of 'anti-model' of a socialist construction (ideologically troublesome for those in power because of its demonstrated effectiveness in terms of implementation), and at the same time as a model example, i.e. one showing the true (in the sense of conformity to the real practice and pragmatics of the time, and not with ideological postulates or the 'decreed' formal legal and organisational state) picture of how investments were actually carried out - not only those of a holiday nature - in the era of People's Poland. His study demonstrates how the genesis of a holiday resort, its formation and subsequent activities reveal various characteristics of the era of People's Poland, in particular the fundamental gap between the official ideology of the 'people's' state and the realities of functioning of both the communist authorities' agencies and the society of Polish inhabitants controlled by them. The case of Ustron-Jaszowiec, like in a lens, reveals some functional antinomies and 'impossibilities' of the then state and society, but at the same time shows the effort (of ordinary people and some of the party-state administrators) to 'manage somehow' in those times marked by communist ideology. In this sense, it is a kind of miniature of communist Poland.

\section{Bibliografia}

Aleksander T., Kultura wypoczynku na wczasach, Warszawa 1986.

Białas Z., Ustroński kurort w latach 1858-1876, „Kalendarz Ustroński” 2011, s. 70-83.

Białas Z., Ustroński kurort w połowie XIX wieku, „Kalendarz Ustroński” 2010, s. 236-253. 
Białas Z., Ustrońskie tazienki borowinowe, „Kalendarz Ustroński” 2003, s. 72-77.

Błasiak W., Szczepański M.S., Wódz J., Szczyrk - miasto w sytuacji inwazji turystycznej (socjologiczne studium uktadu lokalnego), Katowice 1990.

Cieszyn. Zarys rozwoju miasta i powiatu, red. J. Chlebowczyk, Katowice 1973.

Dąbrowski P., Resortowość jako źródto zagrożeń w systemie zarzqdzania kryzysowego, „Prace Geograficzne" 2014, t. LV, s. 19-26.

Dziuba A., Dziurok A., Linek B., Tracz B., Węgrzyn D., Jerzy Ziętek. Konteksty kariery $w$ komunistycznym państwie, Katowice 2018.

Fic M., Między naukq a propaganda. Ślaski Instytut Naukowy im. Jacka Koraszewskiego $w$ Katowicach (1957-1992), Katowice 2014.

Gładysz A., Moje badawcze przygody w Jaszowcu, „Kalendarz Ustroński” 2001, s. 68-71.

Gładysz A., Wczasy w Jaszowcu, Katowice 1974.

Gołkowski W., Generał czynu, „Kalendarz Ustroński” 2000, s. 141-146.

Gonda-Soroczyńska E., Nietypowe połaczenie funkcji uzdrowiskowej z funkcja przemystowa na przykładzie uzdrowiska Ustroń, „Infrastruktura i Ekologia Terenów Wiejskich” 2013, nr 3, s. 31-45.

Gurjanowa H., Jałowiecki B., Przestrzenno-społeczne zagadnienia organizacji wypoczynku, Warszawa 1972.

Guzik H., Działalność uzdrowiskowa w Ustroniu w latach 2000-2006, „Zeszyty Naukowe Uniwersytetu Ekonomicznego w Krakowie" 2010, nr 821, s. 111-128.

Jarosz D., „Masy pracujace przede wszystkim”. Organizacja wypoczynku w Polsce 1945-1956, Warszawa-Kielce 2003.

Kincel R., Lata dwudzieste, lata trzydzieste, „Kalendarz Ustroński” 2004, s. 41-47.

Kincel R., Rozmaitości z poczqtków kurortu, „Kalendarz Ustroński” 2003, s. 37-52.

Korcz P., Lecznictwo ogólne i uzdrowiskowe po 1945 r., w: Ustroń 1305-2005, t. II: 1945-2005, red. L. Szkaradnik, K. Szkaradnik, Ustroń 2007, s. 333-383.

Kubień B., Historia budownictwa w Ustroniu, „Pamiętnik Ustroński” 2001, t. XI, s. 20-39. Lipowczan H., Jaszowiec, Katowice 1970.

Łobodzińska B., Ewolucja założeń programowych wczasów pracowniczych w Polsce Ludowej $w$ latach 1945-1965, w: Wzory spoteczne wakacji $w$ Polsce. Studia i materiaty $z$ badań socjologicznych, red. Z. Skórzyński, A. Ziemilski, t. I, Warszawa 1971, s. 143-184.

Malczewska-Pawelec D., Pawelec T., Akcja ,lato”. Peerelowskie uzdrowisko przygotowuje sie do sezonu (na przyktadzie Ustronia), w: Tradycje i perspektywy rozwoju kultury uzdrowiskowej w Iwoniczu-Zdroju w kontekście europejskim, red. B. Płonka-Syroka, A. Kaźmierczak, S. Jandziś, A. Syroka, Wrocław 2018, s. 341-362.

Michałek A., Rozwój i charakterystyka budownictwa $w$ Ustroniu, w: Ustroń 1305-2005, t. II: 1945-2005, red. L. Szkaradnik, K. Szkaradnik, Ustroń 2007, s. 529-576.

Michałek A., Życie gospodarcze 1945-1989, w: Ustron 1305-2005, t. II: 1945-2005, red. L. Szkaradnik, K. Szkaradnik, Ustroń 2007, s. 671-722.

Migdał K., Psychologia czasu wolnego, Warszawa 2011.

Okrasa R., Organizacja, finansowanie i formy wczasów pracowniczych, Warszawa 1988.

Okrasa R., Wczasy pracownicze. System organizacyjny, Warszawa 1979.

Pilch J., Rozwój Ustronia jako letniska i uzdrowiska (do r. 1939), „Pamiętnik Ustroński” 1989, t. II, s. 3-14.

Pilch M., Jaszowiec, „Pamiętnik Ustroński” 2001, t. XI, s. 73-78.

Płonka-Syroka B., Kultura uzdrowiskowa w Polsce w latach 1918-2012. Społeczno-kulturowe uwarunkowania zmiany jej modelu, w: Zdrowie i choroba. Wptyw jakości życia na kulture $w$ Europie Środkowej, red. A. Barciak, Katowice 2013, s. 174-200.

Sierpiński J., Wczasy pracownicze w Polsce Ludowej. Problematyka ekonomiczna i spoteczna, Warszawa 1968. 
Skórzyński Z., Typologia i zasięg społeczny wzorów wakacyjnych $w$ Polsce $w$ świetle badań reprezentatywnych, w: Wzory społeczne wakacji $w$ Polsce. Studia i materiaty $z$ badań socjologicznych, red. Z. Skórzyński, A. Ziemilski, t. I, Warszawa 1971, s. 209-218.

Skórzyński Z., Wzory społeczne wakacji w Polsce - ważniejsze wyniki badań, w: Wzory spoteczne wakacji $w$ Polsce. Studia i materiały z badań socjologicznych, red. Z. Skórzyński, A. Ziemilski, t. II, Warszawa 1971, s. 305-312.

Sowiński P., Wakacje w Polsce Ludowej. Polityka władz i ruch turystyczny (1945-1989), Warszawa 2005.

Szkaradnik L., Od gminnej do miejskiej Rady Narodowej, w: Ustroń 1305-2005, t. II: 1945-2005, red. L. Szkaradnik, K. Szkaradnik, Ustroń 2007, s. 9-72.

Szkaradnik L., Poczatki i rozwój uzdrowiska, w: Ustroń 1305-2005, t. I: 1305-1945, red. I. Panic, Ustroń 2005, s. 361-380.

Szkaradnik L., Poczatki uzdrowiska w Ustroniu, „Kalendarz Ustroński” 2001, s. 37-43.

Szkaradnik L., Życie społeczne i polityczne do 1990 r., w: Ustroń 1305-2005, t. II: 1945-2005, red. L. Szkaradnik, K. Szkaradnik, Ustroń 2007, s. 117-176.

Szkaradnik L., Żyromski M., Przejawy aktywności kulturalnej w Ustroniu po 1945 r., w: Ustroń 1305-2005, t. II: 1945-2005, red. L. Szkaradnik, K. Szkaradnik, Ustroń 2007, s. 201-269.

Sztwiertnia G., Kombinat uzdrowiskowo-wypoczynkowy, w: Cieszyn. Zarys rozwoju miasta $i$ powiatu, red. J. Chlebowczyk, Katowice 1973, s. 617-631.

Topolski J., Historia $i$ zycie, Lublin 1988.

Tracz B., Ślazak - żotnierz - gospodarz. Jerzy Ziętek jako przykład mitologizacji politycznej, w: A. Dziuba, A. Dziurok, B. Linek, B. Tracz, D. Węgrzyn, Jerzy Ziętek. Konteksty kariery w komunistycznym państwie, Katowice 2018, s. 40-51.

Tradycje i perspektywy rozwoju kultury uzdrowiskowej $w$ Iwoniczu-Zdroju w kontekście europejskim, red. B. Płonka-Syroka, A. Kaźmierczak, S. Jandziś, A. Syroka, Wrocław 2018.

Ustroń 1305-2005, t. I: 1305-1945, red. I. Panic, Ustroń 2005.

Ustroń 1305-2005, t. II: 1945-2005, red. L. Szkaradnik, K. Szkaradnik, Ustroń 2007.

Walczak J., Jerzy Ziętek. Biografia Ślazaka (1901-1985), Katowice 2002.

Walicki R., Polityka społeczna zakładów pracy w sferze wypoczynku urlopowego, Warszawa 1985.

Wzory społeczne wakacji $w$ Polsce. Studia $i$ materiaty $z$ badań socjologicznych, red. Z. Skórzyński, A. Ziemilski, t. I-II, Warszawa 1971.

Zdrowie i choroba. Wptyw jakości życia na kulturę w Europie Środkowej, red. A. Barciak, Katowice 2013.

Tomasz Pawelec - prof. dr hab.; Instytut Historii Uniwersytetu Ślaskiego w Katowicach. Zainteresowania naukowe: polska i amerykańska historiografia w XIX i XX w., zwiąki historii z psychologią i psychoanaliza, najnowsza historia Polski, pamięć zbiorowa, kultura uzdrowiskowa w Europie i w Polsce. E-mail: tomasz.pawelec@us.edu.pl.

Tomasz Pawelec - Prof. dr hab.; Institute of History of the University of Silesia in Katowice. Research interests: Polish and American historiography in the 19th and 20th centuries, links between history and psychology and psychoanalysis, recent Polish history, collective memory, spa culture in Europe and Poland. E-mail: tomasz.pawelec@us.edu.pl. 